\title{
THE MOST VALUABLE ERRATIC BOULDERS IN THE WIELKOPOLSKA REGION OF WESTERN POLAND AND THEIR POTENTIAL TO PROMOTE GEOTOURISM
}

\author{
Maria GÓRSKA-ZABIELSKA* \\ Jan Kochanowski University, Institute of Geography and Environmental Sciences, \\ Uniwersytecka 7 St, 25-401 Kielce, Poland, e-mail: maria.gorska-zabielska@ujk.edu.pl
}

\begin{abstract}
Citation: Górska-Zabielska, M. (2020). THE MOST VALUABLE ERRATIC BOULDERS IN THE WIELKOPOLSKA REGION OF WESTERN POLAND AND THEIR POTENTIAL TO PROMOTE GEOTOURISM. GeoJournal of Tourism and Geosites, 29(2), 694-714. https://doi.org/10.30892/gtg.29225-500
\end{abstract}

\begin{abstract}
In the present paper, twelve erratic boulders in the Wielkopolska region of western Poland are described in detail, indicating their Scandinavian source area, location, form of protection, petrographic type and morphology. In particular, special attention is placed on an evaluation of these boulders' current and potential significance for geotourism with the aim of promoting geotourism. The point bonitation method was used, which took into account scientific, educational, economic and protective values of boulders and other factors. The analysis demonstrated that the Boulder of St. Adalbert has the greatest potential to promote geotourism. All the erratic boulders studied are elements of the geological heritage and are important in the comprehensive geodiversity of the region's natural environment.
\end{abstract}

Key words: Scandinavian erratic boulders, an inanimate nature monument, geodiversity, geological heritage, geotourism, Wielkopolska region

\section{INTRODUCTION}

Erratic boulders, a large fraction of the rock material transported by the Scandinavian Ice Sheet, together with the relief forms of glacial (MIS 2 [marine isotope stage; e.g. Wright, 2000] = and Late Vistulian/Weichselian) and fluvioglacial, fluvial, and aeolian origin are valuable georesources, creating the geomorphological heritage of the Wielkopolska region. Their spatial diversity, together with other natural geological elements, creates the unique geodiversity of the area. This quality determines the geotourism value of the region. Most of the erratic boulders described in this study occur in situ mainly resulting from their size. The final size of a boulder (usually a fragment of rock with a shorter axis length of not less than $50 \mathrm{~cm}$ ) is influenced by several factors, among which the most important is its joint of a massif in the source area. This is a set of cracks and fissures in the rocks that can arise as a result of solidification of magma, tectonic movements and/or weathering. Plutonic and metamorphic rocks are

\footnotetext{
* Corresponding author
} 
predominant among large erratic boulders. Due to good block separateness of this rock type in the source areas, the erratic boulders reach considerable size. Volcanic rocks are significantly less numerous among erratic boulders. Such rocks are characterised by poor block separateness in the source areas therefore the erratic boulders are smaller. Sedimentary rocks, which are susceptible to weathering, do not form large erratic boulders. Only $2 \%$ of large erratic boulders are sedimentary rocks (Schulz, 1996).

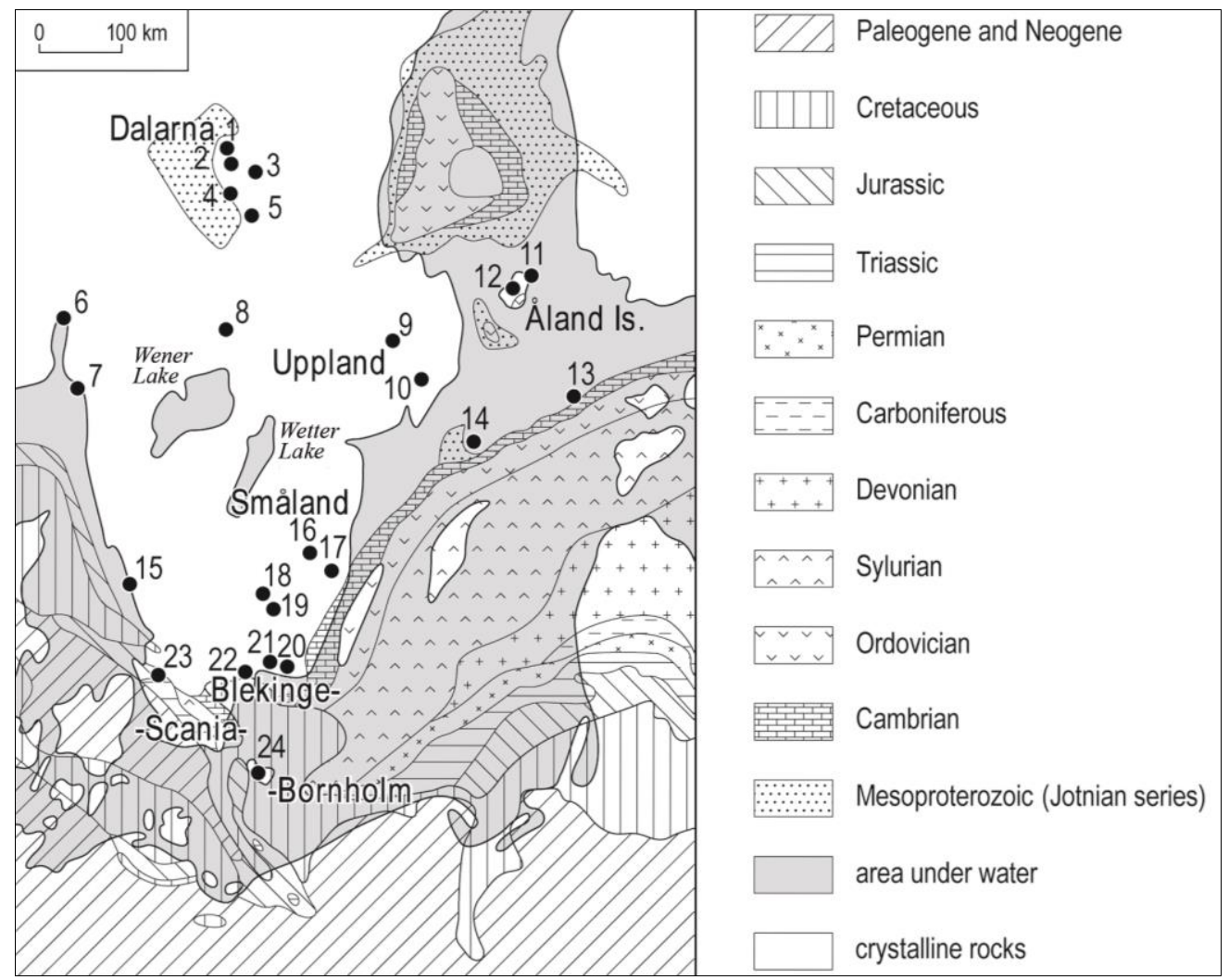

Figure 1. Schematic map of the source area of selected indicator erratic boulders found in the area of glacial deposition, including in the Wielkopolska region. Explanation of numbers:

1 - Bredvad porphyry, 2 - Garberg granite, 3 - Grönklitt porphyry, 4 - Dalarna porphyry, 5 - Siljan granite,

6 - Oslo porphyry, 7 - Bohus granite, 8 - Filipstad granite, 9 - Uppsala granite, 10 - Stockholm granite, $11-\square$ Åland granite and $\square$ Åland rapakivi granite, 12 - Åland quartz porphyry, 13 - red Baltic porphyry, 14 - brown Baltic porphyry, 15 - charnockite, 16 -Småland granite, 17 - Påskallavik porphyry, 18 - grey Växjö granite, 19 - red Växjö granite, 20 - Karlshamn granite, 21 - Halen granite, 22 - Vănga granite, 23 - Scania basalt, 24 - granites and gneisses of Bornholm

The occurrence in situ is of important scientific value in an erratic boulder. This location, unchanged from the time when a boulder was deposited, indicates the presence of an ice-sheet in a given place. Erratic boulders indicate the extent of glaciation, helping to reconstruct Earth's climate history (Reynard, 2004, 2012). Moreover, such boulders are used in recent attempts to date the beginning of the Peribaltic deglaciation through the analyses of in-situ cosmogenic isotopes such as ${ }^{10} \mathrm{Be}$ (Rinterknecht et al., 2005, 2012; Ivy-Ochs and Kober, 2008; Tylmann et al., 2018, 2019) or ${ }^{36} \mathrm{Cl}$ (Dzierżek \& Zreda, 2007). Based on indicator erratics (sensu Lüttig, 1958; Meyer \& Lüttig, 2007) and auxiliary (or 
so-called statistical, sensu Vinx, 1993) erratics it is possible, with great probability, to indicate the source areas (Figure 1) and direction of advance of the Scandinavian Ice Sheet, and its ice streams, that reached central Poland (Górska, 2006; Gałązka, 2004; Czubla, 2015; Górska-Zabielska \& Wachecka-Kotkowska, 2015; Górska-Zabielska et al., 2019a, b, c; Czubla \& Sokołowski, 2019) and thus the Wielkopolska region between 25 and 21 ka BP (Tylmann et al., 2019). Similar research has been conducted in other European (Boulton \& Hagdorn, 2006; Meyer, 2004; Lüttig, 2005) and North American regions (Bouchard \& Salonen, 1989; 1990; DiLabio, 1990; Atkinson, 2007). The research of Dyke \& Morris (1988) and Stokes \& Clark (1999) has shown that the remote transport of rocks from their source area to deposition sites was carried out through ice streams. As a result, they were deposited in the form of Boothia scattering cones.

Examination of the surface of an erratic boulder can identify the processes it underwent during transport inside or at the ice/bed interface. Most often, boulders have a smooth, rounded surface and one of the walls, called the glacial polish, is rather flat. Normally it is formed as a result of scouring against the crystalline bedrock when the boulder was transported in the bottom layer of a moving ice-sheet. Glacial striae are often observed on the glacially polished surface as parallel grooves and/or crescent chatter marks. These microforms of the boulder surface are formed as a result of the subglacial erosional activity of an ice-sheet. Their shape and orientation on an erratic boulder cannot be considered in the context of determining the direction of ice sheet transgression, because erratics are redeposited. On the contrary, when such microforms occur on rocks in the source area they clearly indicate the direction of ice-sheet movement. The morphogenetic processes occurring after the ice-sheet retreat in the zone where a boulder was deposited are also recorded on its surface. Wind abrasion traces are frequently found in a cold and dry periglacial environment. The exfoliation of rocks is also a commonly observed process. The morphological effects of these processes will be presented in the boulder descriptions. Glacial erratics are usually protected legally due to their part in geoheritage (Reynard and Brilha, 2018 and references therein), co-creating geodiversity (Gray, 2013, 2018; Najwer \& Zwoliński, 2014) and their geological and cultural importance. For instance, there are such cases in Germany (Schulz, 1964; Meyer, 1983; Svenson, 2005), Switzerland (Reynard, 2004, 2012, 2015) and in Canada (https://www.alberta.ca/okotoks-erratic-big-rock.aspx). Unfortunately, not all erratics in the Wielkopolska region have been officially listed as protected monuments of inanimate nature. On the other hand, almost all erratic boulders described in this article are entered in the Central Register of Polish Geosites (http://geoportal.pgi.gov.pl/portal/page/ portal/geostanowiska). The inclusion of each erratic boulder on the list of geosites (sensu Reynard, 2004; Migoń, 2012) of the Wielkopolska region should encourage relevant institutions to provide legal protection to all valuable geological objects.

Many erratic boulders, not only those in Wielkopolska, belong to their region's cultural heritage and appear in folk legends, tales (Grimmberger, 2017) or serve as protector beings (Motta \& Motta, 2007). Some boulders have been named after saints or prominent figures; sometimes their shape resembles a particular object and hence their name. Symbols, letters and inscriptions have been carved onto the surface of some erratic boulders. Erratic boulders have served as border posts in the past and are of important historical value. Although there are no examples from the Wielkopolska region, there are at least two such boulders in northern Poland (Górska-Zabielska \& Kamieńska, 2017) and one in the central Poland (Górska-Zabielska et al., 2019a, c). Erratic boulders play an educational and geohistorical role as they have been used to commemorate important historical events (Reynard et al., 2009; Górska-Zabielska, 2010, 2019a, c). Their educational 
value is demonstrated in 'green school' programs or geocaching (Zecha \& Schiller, 2015). Both students and tourists who visit an erratic boulder should receive an explanation of, among other things, processes such as glacial erosion, transport and accumulation.

Large erratic boulders have geotourism potential, although this has not been widely reported nor appreciated so far (Reynard, 2004, 2015; Reynard et al., 2009; GórskaZabielska, 2015, 2019b; Górska-Zabielska \& Dobracki, 2015; Górska-Zabielska \& Zabielski, 2018; Duraj et al., 2017; Chylińska \& Kołodziejczyk, 2018). Only the aesthetic value of boulders is commonly appreciated with tourists often taking pictures of themselves against the backdrop of these objects. The appropriate geological description, perhaps in the form of an information board or leaflet, presented with a wider background of the geodiversity of a region would be valuable. In this way tourists can not only admire the beauty of a boulder but also learn about its significance within the geological history of the region. It is also necessary to stress the importance of erratic boulders in the reconstruction of the geological past of an area (Reynard, 2008).

Unfortunately, there are only a few information boards next to the boulders in the Wielkopolska region. There are, however, examples in other parts of Poland where local authorities provide appropriate background information (Górska-Zabielska \& Dobracki, 2015; Górska-Zabielska, 2019). The perception, recognisability and role of erratic boulders in the natural environment are still little known (Górska-Zabielska \& Zabielski, 2018; Górska-Zabielska et al., 2019b). This partly results from the lack of awareness of the importance of these objects in the geological and cultural heritage of a region. At the same time, in the absence of unambiguous legal regulations that would clearly protect these geological objects, erratic boulders can disappear irretrievably from fields and forests (Górska-Zabielska, 2016) as they are used in the production of gravestones and other stone accessories (Chrząszczewski, 2009; Piotrowski, 2008).

The erratic boulders that are most attractive in terms of shape and colouration occasionally disappear from baulks and forests and appear as decorations in private gardens. Unfortunately, large erratic boulders are also used as surfaces for graffiti.

\section{PURPOSE OF RESEARCH}

The main goal of the present paper is to estimate the potential of Wielkopolska erratic boulders for the development of geotourism in the region. For this purpose a point bonitation method was used. The described in details and evaluated in this paper glacial boulders, have appeared in the Polish literature in form of short notes. The boulders have been mentioned in older studies published in Polish by Szulczewski (1924), Głowińska (1932) and Krawiec (1933) and recently aroused the interest of the author (GórskaZabielska, 2010, 2015b). Some boulders in Wielkopolska have been subject of the ${ }^{10} \mathrm{Be}$ exposure age analysis recently (Tylmann et al., 2019). These indicators of the ice sheet retreat after the Local Last Glacial Maximum are important scientific values which rise geoturistic attractiveness of the erratic boulders. Neither the selected boulders nor any other erratic boulders from the Wielkopolska region have ever been subject of evaluation analysis towards indicating their potential to promote geotourism.

Before erratic boulders disappear completely from our landscape, it is worth making efforts to rescue them from oblivion. Therefore this article aims to serve this purpose as well. It presents 12 erratic boulders as examples of the geodiversity of the Wielkopolska region. The descriptions include dimensions for length (a), width (b), height (c), perimeter, volume and weight. The volume of the rock is calculated according to the formula: $\mathrm{V}=0.523 \times \mathrm{x} \mathrm{a} \mathrm{b} \mathrm{x} \mathrm{c} \mathrm{[m^{3 } ]}$ (Schulz, 1964; Speetzen, 1998) and its weight taking into account the dependence: $1 \mathrm{~m}^{3}=2.7-2.8$ tons (Table 1 ). 
Table 1. Basic information about the erratic boulders studied in the Wielkopolska region

\begin{tabular}{|c|c|c|c|c|c|c|c|c|c|c|c|c|}
\hline 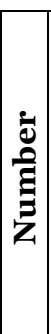 & 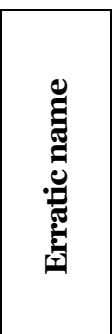 & 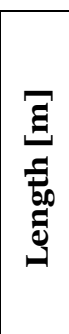 & 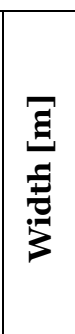 & 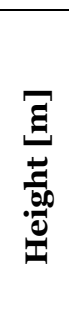 & 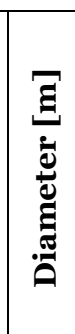 & $\begin{array}{l}\bar{g} \\
\dot{\Xi} \\
\dot{0}\end{array}$ & $\begin{array}{l} \pm \\
\pm \\
\pm \\
\frac{01}{00} \\
3\end{array}$ & 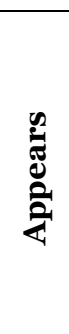 & . & 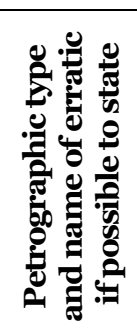 & 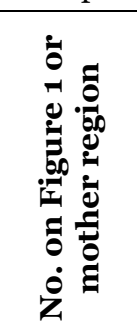 & 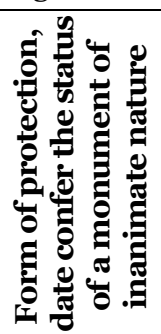 \\
\hline 1 & 胥 & 250 & 190 & 145 & 710 & 3.6 & 9.91 & $\begin{array}{l}e x \\
\text { situ }\end{array}$ & $\begin{array}{l}52^{\circ} 35^{\prime} 18,1^{\prime \prime N} \\
16^{\circ} \mathrm{O} 1^{\prime} 34,1^{\prime \prime} \mathrm{E}\end{array}$ & $\begin{array}{l}\text { Småland } \\
\text { granite }\end{array}$ & 16 & $\begin{array}{c}\text { Monument } \\
\text { of inanimate } \\
\text { nature, } \\
\text { 30.01.2003 }\end{array}$ \\
\hline 2 & $\underset{\Xi}{\Xi}$ & 350 & 270 & 125 & 1200 & 6.18 & 17 & $\begin{array}{l}\text { in } \\
\text { situ }\end{array}$ & $\begin{array}{l}52^{\circ} 38^{\prime} 12,1^{\prime \prime N} \\
16^{\circ} 08^{\prime} 59,1^{\prime \prime} \mathrm{E}\end{array}$ & $\begin{array}{l}\text { Småland } \\
\text { granite }\end{array}$ & 16 & $\begin{array}{c}\text { Monument } \\
\text { of inanimate } \\
\text { nature, } \\
6.02 .1997\end{array}$ \\
\hline 3 & 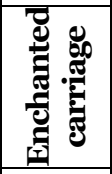 & 250 & 200 & 150 & $\begin{array}{c}410 \\
(640)\end{array}$ & 3.92 & 10.7 & $\begin{array}{l}\text { in } \\
\text { situ }\end{array}$ & $\begin{array}{l}53^{\circ} \mathrm{O} 2^{\prime} 37,6^{\prime \prime N} \\
17^{\circ} \mathrm{O} 6^{\prime} 55,6^{\prime \prime} \mathrm{E}\end{array}$ & $\begin{array}{l}\text { Åland } \\
\text { rapakivi } \\
\text { granite }\end{array}$ & 11 & $\begin{array}{l}\text { Monument } \\
\text { of inanimate } \\
\text { nature, } 1957\end{array}$ \\
\hline 4 & 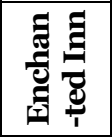 & 650 & 3400 & 230 & 1600 & 26.6 & 73.1 & $\begin{array}{l}\text { in } \\
\text { situ }\end{array}$ & $\begin{array}{l}52^{\circ} 57^{\prime} 13,4^{\prime \prime N} \\
17^{\circ} \mathrm{O} 7^{\prime} 31,7^{\prime \prime E}\end{array}$ & gneiss & - & $\begin{array}{c}\text { Monument } \\
\text { of inanimate } \\
\text { nature, } \\
28.03 .1957\end{array}$ \\
\hline 5 & $\begin{array}{ll} \\
0\end{array}$ & 725 & 480 & $\begin{array}{c}400 \\
130 a . s \\
\text { 1.) }\end{array}$ & 2000 & $\begin{array}{c}72.8 \\
\text { of } \\
\text { entire } \\
\text { boul } \\
- \text { der } \\
\end{array}$ & $\begin{array}{c}200.2 \\
\text { of } \\
\text { entire } \\
\text { boul } \\
\text {-der }\end{array}$ & $\begin{array}{l}\text { in } \\
\text { situ }\end{array}$ & $\begin{array}{c}52^{\circ} 43^{\prime} 33, \mathrm{O}^{\prime \prime N} \\
17^{\circ} 19^{\prime} 22,4^{\prime \prime} \mathrm{E}\end{array}$ & $\begin{array}{l}\text { Småland } \\
\text { granite }\end{array}$ & 16 & $\begin{array}{l}\text { Monument } \\
\text { of inanimate } \\
\text { nature, } 1840\end{array}$ \\
\hline 6 & 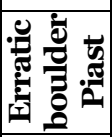 & 240 & 210 & 800 & ? & ? & ? & $\begin{array}{l}\text { in } \\
\text { situ }\end{array}$ & $\begin{array}{l}52^{\circ} 36^{\prime} 11,1^{\prime \prime} \mathrm{N} \\
18^{\circ} 23^{\prime} 37,5^{\prime \prime} \mathrm{E}\end{array}$ & $\begin{array}{l}\text { Småland } \\
\text { granite }\end{array}$ & 16 & $\begin{array}{l}\text { Monument } \\
\text { of inanimate } \\
\text { nature }\end{array}$ \\
\hline 7 & 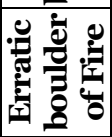 & 100 & 60 & ? & ? & ? & ? & $\begin{array}{l}\text { in } \\
\text { situ }\end{array}$ & $\begin{array}{l}52^{\circ} 33^{\prime} 27,2^{\prime \prime N} \\
18^{\circ} 22^{\prime} 24,3^{\prime \prime} \mathrm{E}\end{array}$ & $\begin{array}{l}\text { Småland } \\
\text { granite }\end{array}$ & 16 & $\begin{array}{l}\text { Monument } \\
\text { of inanimate } \\
\text { nature }\end{array}$ \\
\hline 8 & 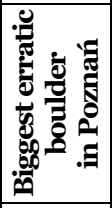 & 450 & 420 & 550 & 1200 & 54.4 & 149.5 & $\begin{array}{l}e x \\
\text { situ }\end{array}$ & $\begin{array}{l}51^{\circ} 57^{\prime} 56,9^{\prime \prime N} \\
17^{\circ} \mathrm{O} 9^{\prime} 05,8^{\prime \prime} \mathrm{E}\end{array}$ & gneiss & - & - \\
\hline 9 & 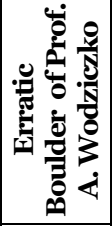 & 170 & 60 & 105 & 455 & 0.56 & 1.54 & $\begin{array}{l}e x \\
\text { situ }\end{array}$ & $\begin{array}{l}52^{\circ} 14^{\prime} 59, \mathrm{o}^{\prime \prime N} \\
16^{\circ} 48^{\prime} 58,1^{\prime \prime} \mathrm{E}\end{array}$ & $\begin{array}{l}\text { Järeda } \\
\text { granite }\end{array}$ & Småland & - \\
\hline 10 & $\begin{array}{cc}0 \\
0\end{array}$ & 300 & 265 & 210 & 1000 & 8.73 & $\begin{array}{c}25.24 \\
\text { twei- } \\
\text { ghed } \\
! ! !\end{array}$ & $\begin{array}{l}\text { ex } \\
\text { situ }\end{array}$ & $\begin{array}{l}52^{\circ} 14^{\prime} 15,6^{\prime \prime N} \\
16^{\circ} 55^{\prime} 42, \mathrm{o}^{\prime \prime} \mathrm{E}\end{array}$ & $\begin{array}{c}\text { Småland } \\
\text { granite }\end{array}$ & 16 & - \\
\hline
\end{tabular}


The Most Valuable Erratic Boulders in the Wielkopolska Region of Western Poland and their Potential to Promote Geotourism

\begin{tabular}{|c|c|c|c|c|c|c|c|c|c|c|c|c|}
\hline 11 & 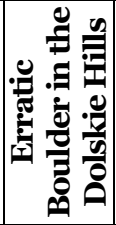 & 430 & 350 & 130 & 1200 & 10.26 & 28.22 & $\begin{array}{l}\text { in } \\
\text { situ }\end{array}$ & $\begin{array}{l}51^{\circ} 57^{\prime} 56,9^{\prime \prime N} \\
17^{\circ} \mathrm{O} 9^{\prime} 05,8^{\prime \prime} \mathrm{E}\end{array}$ & $\begin{array}{l}\text { Jotnian } \\
\text { sand- } \\
\text { stone }\end{array}$ & $\begin{array}{c}\text { Mainly Dalarna } \\
\text { and/ or } \\
\text { Cambrian } \\
\text { outcrops in } \\
\text { the Baltic Sea }\end{array}$ & $\begin{array}{c}\text { Monument } \\
\text { of inanimate } \\
\text { nature, } \\
29.08 .1956\end{array}$ \\
\hline 12 & 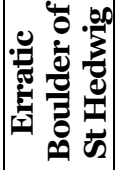 & 800 & 500 & 400 & 2200 & 73 & 200 & $\begin{array}{l}\text { in } \\
\text { situ }\end{array}$ & $\begin{array}{l}51^{\mathrm{o}} 51^{\prime} 09,3^{\prime \prime} \mathrm{N} \\
17^{\circ} 55^{\prime} 51,3^{\prime \prime} \mathrm{E}\end{array}$ & $\begin{array}{l}\text { Småland } \\
\text { granite }\end{array}$ & 16 & $\begin{array}{c}\text { Monument } \\
\text { of inanimate } \\
\text { nature, } \\
28.03 .1957\end{array}$ \\
\hline
\end{tabular}

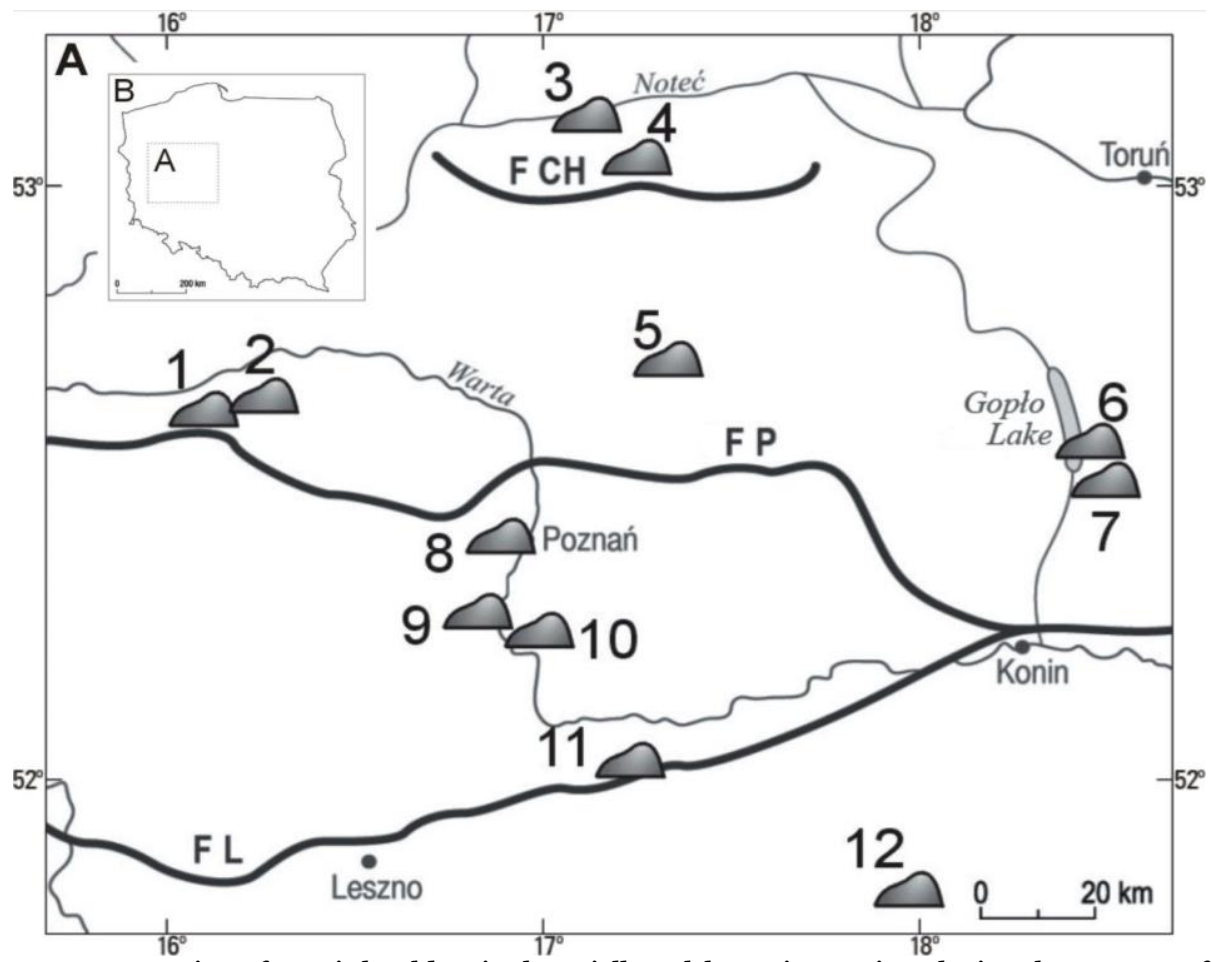

Figure 2a. Location of erratic boulders in the Wielkopolska region against the ice-sheet extent of the

Vistulian glaciation (MIS 2); 2b. Location of the Wielkopolska region on the map of Poland

F L - Leszno (Brandenburg) Phase 20 ka BP, SF P - Poznań (Frankfurt) Phase 18.8 ka BP, F CH -

Chodzież (Kolmar) Phase 17.7 ka BP (extent lines, age and names: Liedtke 1981; Kozarski 1995).

Erratic boulders: 1 - Johnny; 2 - Lutom; 3 - Enchanted Carriage; 4 - Enchanted Inn; 5 - Boulder of St. Adalbert; 6 - Piast; 7 - Boulder of Fire; 8 - The largest boulder in Poznań; 9 - Boulder of Professor A.

Wodziczko; 10 - Boulder in Rogalin; 11 - Boulder in Dolskie Hills; and 12 - Boulder of St. Hedwig

An important part of the boulder descriptions is their petrographic type. Great emphasis was placed on this issue, taking into account the gaps (CzernickaChodkowska, 1983), and sometimes serious errors, in the existing documents (e.g., the list of inanimate nature monuments kept in the Regional Directorate for Environmental Protection in Poznań), lists and information boards (Górska-Zabielska, 2010).

If a boulder is an indicator erratic (sensu Lüttig, 1958; Meyer \& Lüttig, 2007), its Scandinavian provenance is given for the first time (except for the Polish literature) and 
this source region is marked on a schematic map (Figure 1). Twelve erratic boulders in the Wielkopolska region (Figure 2) are presented and evaluated in this study to estimate their potential to promote geotourism. They have been selected, according to the author's field work within the study area, experience, and comparison with other studies (e.g., Treichel, 1959; Meyer, 2004; Reynard, 2004; Obst, 2005; Svenson, 2005; Górska-Zabielska, 2015b; Górska-Zabielska \& Dobracki, 2015; Woźniak et al., 2015; Górska-Zabielska et al., 2019a, c), due to their above-average scientific, educational, cultural and aesthetic value. This perspective takes an interdisciplinary scientific approach to the issue (Reynard, 2005; Reynard et al., 2009). Each erratic boulder has been studied in terms of its significance to the natural and/or cultural heritage of the region, that is its importance for the development of social identity (Reynard et al., 2009).

\section{EVALUATION ANALYSIS}

Twelve erratic boulders, which are part of geological heritage of the region, were evaluated in detail (Table 3). Considering the importance of these objects for local geotourism, the following values were assessed: scientific, educational, economic, conservation and additional (Table 2). The grading method used in this study was already applied in similar cases (among others Pereira et al., 2007; Bruschi \& Cendrero, 2005, 2009; Kubalíková, 2013; Górska-Zabielska \& Kamieńska, 2017, Górska-Zabielska et al., 2019c). Recently Brilha (2016) reviewed the procedures used in the development of a systematic site inventory applied to different scales and values. As a consequence, he proposed a new approach to the concepts of geosite and geodiversity site in context of effective geodiversity inventories to support geoparks' strategies. The criteria for evaluation were selected specially for the purposes of this work and the specificity of the region.

Table 2. Categories, criteria and scoring used in this study to evaluate the potential for erratic boulders in the Wielkopolska region to promote geotourism

\begin{tabular}{|c|c|c|c|c|}
\hline \multirow{2}{*}{ CATEGORY } & \multirow{2}{*}{ CRITERION } & \multicolumn{3}{|c|}{ SCORE } \\
\hline & & $\mathbf{0}$ & 0.5 & $\mathbf{1}$ \\
\hline \multirow{4}{*}{$\begin{array}{c}\text { SCIENTIFIC } \\
\text { VALUE } \\
{[\max 4} \\
\text { points] }\end{array}$} & $\begin{array}{l}\text { Location after } \\
\text { ice thawing }\end{array}$ & ex situ & $\begin{array}{l}\text { within } 20 \text { metres from } \\
\text { the excavation site }\end{array}$ & in situ \\
\hline & Type of erratic & none & so called statistical & indicator \\
\hline & $\begin{array}{l}\text { Geodiversity (number } \\
\text { of different features } \\
\text { or processes visible } \\
\text { in geosite) }\end{array}$ & $\begin{array}{c}\text { only } 1 \text { visible } \\
\text { feature/process }\end{array}$ & $\begin{array}{l}\text { 2-4 visible features } \\
\text { /processes }\end{array}$ & $\begin{array}{c}\text { more than } 5 \\
\text { visible features / } \\
\text { processes }\end{array}$ \\
\hline & $\begin{array}{l}\text { Scientific } \\
\text { knowledge }\end{array}$ & $\begin{array}{c}\text { lack }=\text { not } \\
\text { investigated site }\end{array}$ & $\begin{array}{l}\text { scientific paper in a } \\
\text { national journal }\end{array}$ & $\begin{array}{c}\text { extensive knowledge } \\
\text { of the site, published } \\
\text { monography }\end{array}$ \\
\hline \multirow{4}{*}{$\begin{array}{l}\text { EDUCA- } \\
\text { TIONAL } \\
\text { VALUE } \\
{[\text { max } 4} \\
\text { points] }\end{array}$} & $\begin{array}{l}\text { Representativeness } \\
\text { and visibility/ } \\
\text { clarity of features } \\
\text { /processes }\end{array}$ & $\begin{array}{l}\text { weak representati- } \\
\text { veness /clarity of } \\
\text { form and process }\end{array}$ & $\begin{array}{c}\text { medium } \\
\text { representativeness, } \\
\text { mainly for specialists }\end{array}$ & $\begin{array}{l}\text { high } \\
\text { representativeness } \\
\text { of form and process, } \\
\text { also for amateurs }\end{array}$ \\
\hline & $\begin{array}{c}\text { Quality of educational } \\
\text { example, educational } \\
\text { usefulness }\end{array}$ & $\begin{array}{c}\text { weak example, weak } \\
\text { educational usefulness } \\
\text { of form and process }\end{array}$ & $\begin{array}{l}\text { good example but of } \\
\text { limited educational } \\
\text { usefulness }\end{array}$ & $\begin{array}{l}\text { very good example with } \\
\text { high educational and } \\
\text { geotourist usefulness }\end{array}$ \\
\hline & $\begin{array}{l}\text { Existing educational } \\
\text { products }\end{array}$ & lack & $\begin{array}{l}\text { leaflets, maps, } \\
\text { web pages }\end{array}$ & $\begin{array}{c}\text { information boards, } \\
\text { information next to } \\
\text { the site }\end{array}$ \\
\hline & $\begin{array}{l}\text { Existing forms of use } \\
\text { for educational } \\
\text { purposes (specialist } \\
\text { tour, guided tour) }\end{array}$ & $\begin{array}{c}\text { lack of } \\
\text { educational use }\end{array}$ & $\begin{array}{c}\text { site is a part of } \\
\text { specialist tour (eg. for } \\
\text { students, geotourists) }\end{array}$ & $\begin{array}{l}\text { guided tour for the } \\
\text { general public }\end{array}$ \\
\hline
\end{tabular}


The Most Valuable Erratic Boulders in the Wielkopolska Region of Western Poland and their Potential to Promote Geotourism

\begin{tabular}{|c|c|c|c|c|}
\hline \multirow{3}{*}{$\begin{array}{c}\text { ECONOMIC } \\
\text { VALUE } \\
\text { [max } 3 \\
\text { points] }\end{array}$} & Accessibility & $\begin{array}{l}\text { restricted access } \\
\text { (e.g. private area) }\end{array}$ & $\begin{array}{l}\text { unrestricted access, } \\
\text { less than } 1000 \mathrm{~m} \\
\text { from the car park }\end{array}$ & $\begin{array}{l}\text { unrestricted access, less } \\
\text { than } 1000 \text { m from the } \\
\text { public transport stop }\end{array}$ \\
\hline & $\begin{array}{l}\text { Presence of tourist } \\
\text { infrastructure } \\
\text { (picnic area, shop, } \\
\text { accommodation) }\end{array}$ & $\begin{array}{l}\text { more than } 10 \mathrm{~km} \\
\text { from the existing } \\
\text { tourist facilities }\end{array}$ & $\begin{array}{l}5-10 \mathrm{~km} \text { from } \\
\text { the existing } \\
\text { tourist facilities }\end{array}$ & $\begin{array}{l}\text { less than } 5 \mathrm{~km} \text { from } \\
\text { the existing tourist } \\
\text { facilities }\end{array}$ \\
\hline & Local products & lack & several products & $\begin{array}{l}\text { the placeis a symbol for } \\
\text { several local products }\end{array}$ \\
\hline \multirow{4}{*}{$\begin{array}{l}\text { CONSER } \\
\text {-VATION } \\
\text { VALUE } \\
\text { [max } 4 \\
\text { points] }\end{array}$} & $\begin{array}{c}\text { Existing threats } \\
\text { and the risk of damage }\end{array}$ & $\begin{array}{c}\text { natural and } \\
\text { anthropogenic threats }\end{array}$ & $\begin{array}{l}\text { threat that may } \\
\text { destroy the site }\end{array}$ & $\begin{array}{l}\text { low risk and almost } \\
\text { non-existing threat }\end{array}$ \\
\hline & $\begin{array}{l}\text { Potential threats } \\
\text { and the risk of damage }\end{array}$ & $\begin{array}{c}\text { natural and } \\
\text { anthropogenic threats }\end{array}$ & $\begin{array}{l}\text { threat that may } \\
\text { destroy the site }\end{array}$ & $\begin{array}{l}\text { low risk and almost } \\
\text { non-existing threat }\end{array}$ \\
\hline & Current state & $\begin{array}{c}\text { continuous } \\
\text { destruction } \\
\text { of the site }\end{array}$ & $\begin{array}{l}\text { destroyed site but the } \\
\text { action is taken to stop } \\
\text { further destruction }\end{array}$ & no destruction \\
\hline & $\begin{array}{l}\text { Legal protection } \\
\text { status }\end{array}$ & $\begin{array}{l}\text { lack of legal } \\
\text { protection }\end{array}$ & $\begin{array}{l}\text { existing legal } \\
\text { protection }\end{array}$ & $\begin{array}{c}\text { effective legal } \\
\text { protection in form of } \\
\text { an abiotic monument }\end{array}$ \\
\hline \multirow{4}{*}{$\begin{array}{l}\text { ADDED } \\
\text { VALUE } \\
{[\max 4,5} \\
\text { points] }\end{array}$} & $\begin{array}{l}\text { Cultural values } \\
\text { (historical, } \\
\text { archaeological, } \\
\text { religious) connected } \\
\text { with the abiotic site }\end{array}$ & lack & $\begin{array}{l}\text { existing cultural } \\
\text { values but without } \\
\text { a close connection } \\
\text { with the abiotic site }\end{array}$ & $\begin{array}{l}\text { existing cultural } \\
\text { values in close } \\
\text { connection with } \\
\text { the abiotic site }\end{array}$ \\
\hline & Ecological value & unimportant & $\begin{array}{l}\text { existing influence } \\
\text { but without much } \\
\text { significance }\end{array}$ & $\begin{array}{c}\text { important influence of } \\
\text { geomorphological } \\
\text { features on ecological } \\
\text { value of the site } \\
\end{array}$ \\
\hline & \multirow{2}{*}{$\begin{array}{l}\text { Aesthetic value } \\
\text { (number of colours, } \\
\text { structure types, } \\
\text { viewpoints, exposed } \\
\text { position, volume) }\end{array}$} & $\begin{array}{c}0-1 \text { colour, } \\
0.25-2-3 \text { colours, } \\
0.5-\text { more than } \\
3 \text { colours }\end{array}$ & $\begin{array}{c}\text { O - only } 1 \text { structure, } \\
\text { o.25- } 2-3 \text { clearly } \\
\text { distinguishable } \\
\text { structures, } \\
\text { o.5 - more than } 3 \\
\text { structures }\end{array}$ & \multirow{2}{*}{$\begin{array}{c}\text { O- lack of } \\
\text { observation points, } \\
\text { 0.25-1-2 } \\
\text { observation points, } \\
\text { o.5 }-3 \text { and more } \\
\text { observation points }\end{array}$} \\
\hline & & $\begin{array}{l}\mathrm{O}-\text { no exposed } \\
\text { position } \\
0.5-\text { exposed } \\
\text { position }\end{array}$ & $\begin{array}{c}\mathrm{O} \text { - volume below } 1 \mathrm{~m}^{3} \\
\text { o.25 - volume } \\
\text { between } 1 \text { and } 2 \mathrm{~m}^{3} \\
\text { o.5- volume more } \\
\text { than } 2 \mathrm{~m}^{3}\end{array}$ & \\
\hline
\end{tabular}

The category scientific value was evaluated based on four criteria: occurrence in/ex situ, type of erratic, the number of features evidencing the geological processes affecting a boulder and scientific investigations of a boulder. The category educational value was evaluated based on four criteria: representativeness and clarity of identification of geological process, quality of educational values, existing educational materials and existing educational trails. The category economic value was evaluated based on three criteria: accessibility, presence of tourist infrastructure and available local products. The category conservation value was evaluated based on four criteria: existing threats and the risk of damage, potential threats and the risk of damage, current state and legal protection status. The category of additional value was evaluated based on three criteria: existence of cultural values, ecological values and aesthetic values. Within the abovementioned criteria there is little to evaluate the potential of erratic boulders to promote geotourism. The latest research (Górska-Zabielska et al., 2019b) indicates these are 
mainly: existing educational materials containing information on erratic boulders, existing trails providing easy access to boulders, as well as the presence of aesthetic values, which may attract a geotourist to the geosite. Information by a specialist is also welcome.

\section{DESCRIPTION OF ERRATIC BOULDERS}

Jaś (Eng. Johnny), Sieraków Landscape Park (No. 1 in Figure 2); $\Phi: 5^{\circ}$

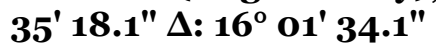

The boulder is an indicator erratic-Småland granite-with outcrops occurring in southeastern Sweden (Figure 1). The smooth surfaces and rounded edges of the boulder are evidence of the destructive effect of the ice-sheet. Some fragments of boulder surface reveal intensive physical weathering (exfoliation) (Figure 3).

The boulder is situated on a dirt road connecting the neighbouring villages within Sieraków Landscape Park and is easily accessible. A bike trail (the blue trail) and the National Uprising Route run along the dirt road. A plaque on the boulder commemorates an important local historical event on March 10, 1769. It was then that 300 confederates ended their young lives, while standing up for the sovereignty of their homeland against the growing Russian omnipotence and the appropriation of the country. Therefore, the boulder plays important educational, geohistorical and culture-forming functions.

The erratic boulder has good visibility and is accompanied by an information board. However, the glacial origin of the erratic boulder and its status as an inanimate nature monument are not mentioned on the board. A complete information about this erratic boulder would be an invaluable help for the inhabitants and geotourists.

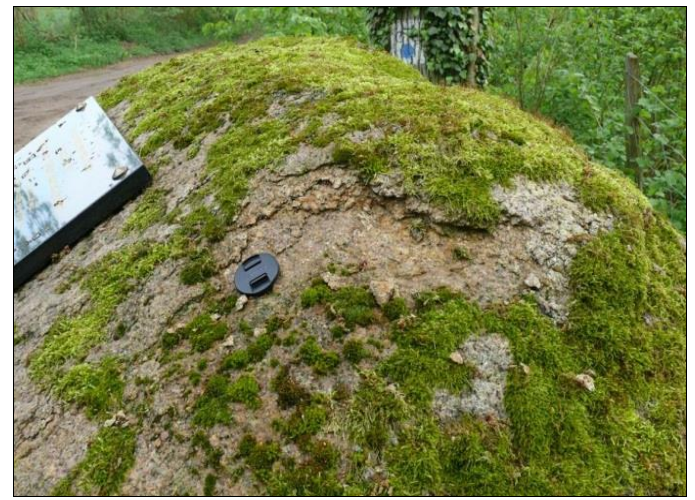

Figure 3. The top surface of the boulder Johnny undergoes physical weathering (exfoliation)

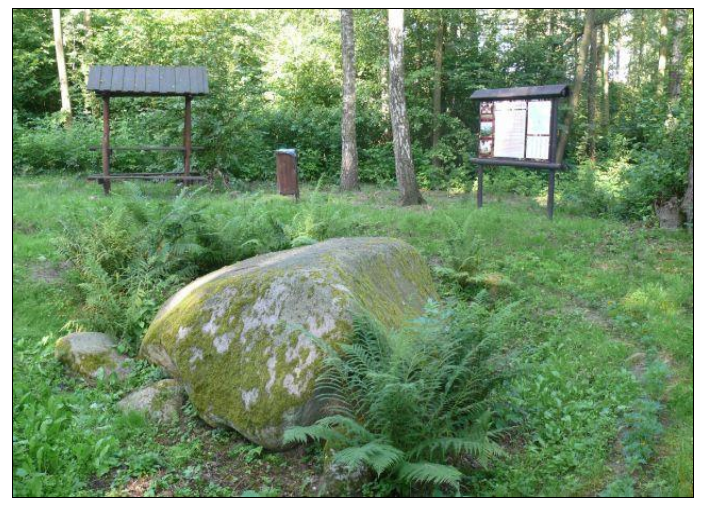

Figure 4. Properly equipped geosite of the Lutom boulder in the Sieraków Landscape Park

\section{Lutom (also known as the Devil's Stone), Sieraków Landscape Park} (No. 2 in Figure 2); $\Phi: 52^{\circ} 3^{\prime}$ 12.1" $^{\prime \prime} \Delta$ : $^{\circ}{ }^{\circ}$ o8' $^{\prime} 59.1^{\prime \prime}$

The boulder is an indicator erratic-Småland granite-with outcrops occurring in southeastern Sweden (Figure 1). Despite the fact that its surface is colonised by epilithic flora the boulder's rounded edges and smooth walls can be observed, which indicates it was subjected to glacial erosion when it was transported by the ice-sheet. The erratic boulder occurs in the forest to the north of the village of Lutom, on the east side of Lake Lutomskie in Sieraków Landscape Park. Although originally the top surface of the boulder was even with the terrain, today it has been unearthed. The information boards and a tourist shelter make it a model stop for geotourism in the region (Figure 4). Access to the boulder is easier now with a gravel road and signposts leading to it. However, the distance 
of the boulder from the asphalt road can make it unattractive for motorised tourists because the gravel road is only passable for bicycles or forest service vehicles. The boulder has high scientific and educational value due to its above-average size, occurrence in situ in Sieraków Landscape Park, and that it is protected as a monument of inanimate nature.

Zaczarowana Karoca (Eng. Enchanted Carriage; also known as the Devil's Vehicle) in the Torun-Eberswalde Pradolina (No. 3 in Figure 2); $\Phi$ : $53^{\circ}{ }^{\circ} 2^{\prime} 37.6^{\prime \prime} \Delta: 1^{\circ}{ }^{\circ} 6^{\prime} 55.6^{\prime \prime}$.

This erratic boulder has high geovalues due to its occurrence in situ on the first high terrace of the Toruń-Eberswalde Pradolina (ice-marginal valley), the type of rockindicator erratic-rapakivi granite from the Åland Islands (Figures 1, 6), and the irregular, fanciful shape indicating strong weathering (Figure 5). All these features were already appreciated in 1957 when the boulder was put under legal protection as an inanimate nature monument. The boulder was a local landmark where dirt roads intersected with each other. Therefore, access to the boulder is simple as it is situated at a crossroads in the western section of the small village of Atanazyn.

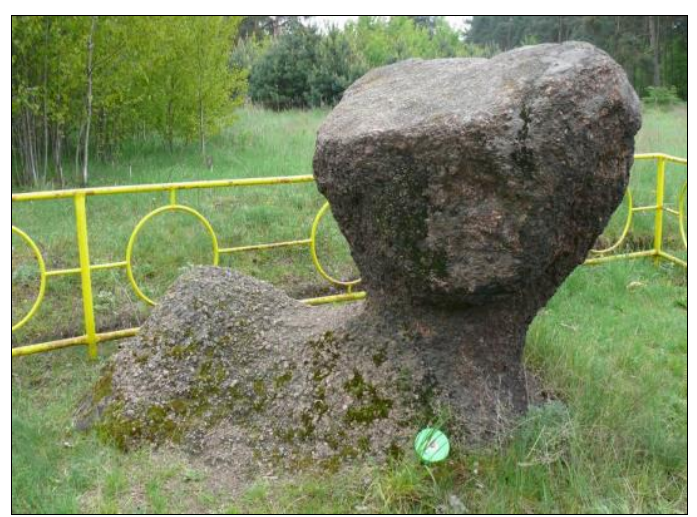

Figure 5. Enchanted carriage in the TorunEberswalde Pradolina is a strongly weathered indicator erratic of Åland rapakivi granite

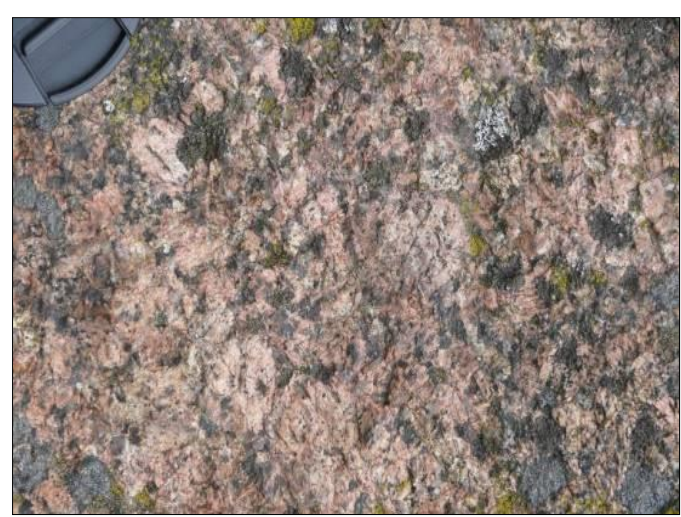

Figure 6. Details of the structure and texture of the Åland rapakivi granite of the Enchanted carriage

Zaklęta Karczma (Enchanted Inn) in northern Wielkopolska (No. 4 in Figure 2); $\Phi: 52^{\circ} 57^{\prime} 13.4^{\prime \prime} \Delta: 17^{\circ} 07^{\prime} 31.7^{\prime \prime}$

This erratic boulder is a gneiss without a known specific origin, only that it originated in the Scandinavian Baltic Shield. The boulder surface is smoothed as a result of the destructive activity of the ice-sheet. This in situ boulder was dated with ${ }^{10} \mathrm{Be}$ by Tylmann et al. (2019). Its ${ }^{10} \mathrm{Be}$ exposure age is $17.1+/-1.6 \mathrm{ka}$, which is an important scientific value of the object and influences its geoturistic attractiveness.

Although the boulder is situated in a private field, access to it is indicated by a signpost. Moreover, it occurs under a high branched fruit tree that can be seen from a distance (Figure 7). The boulder may be taller than the tree because its lower part is below ground level. At the base of the boulder the following inscription (in Polish) is visible (Figure 8; here translated): ...IN MEMORY OF MY MOTHER / ANTONINA NÉE GARCZYŃSKA / H. SKÓRZEWSKA / TEODOR COUNT SKÓRZEWSKI / ---HRZE: 1825(7).

Owing to this inscription, the boulder can be rated among the few objects of cultural heritage in the Wielkopolska region. The boulder is an inanimate nature monument and was entered in the register as early as 1957. Unfortunately, this does not protect it against vandalism in the form of graffiti. 


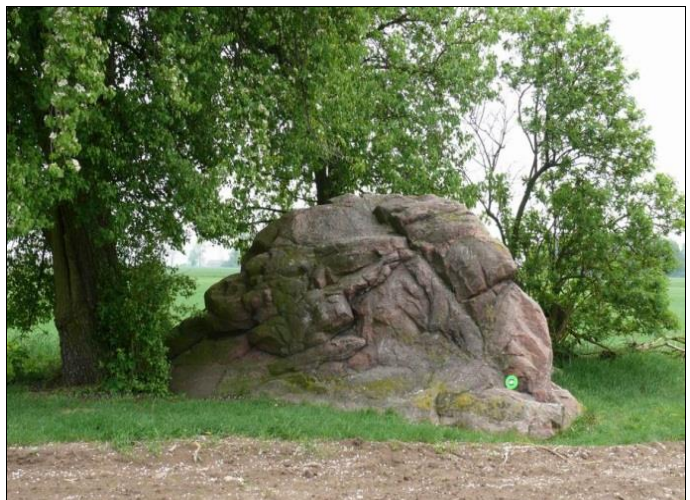

Figure 7. Enchanted Inn-general view

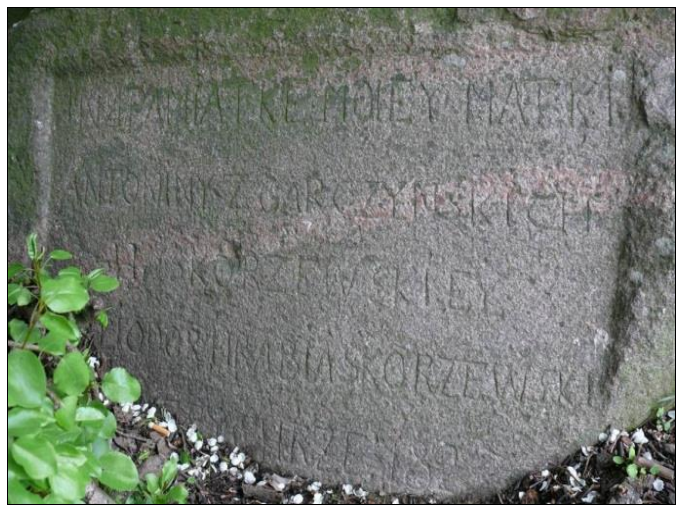

Figure 8. Inscription of Count Skórzewski engraved at the base of the boulder

Głaz Św. Wojciecha (Eng. Boulder of St. Adalbert; No. 5 in Figure 2); $\Phi$ : $52^{\circ} 43^{\prime} 33.0 " \Delta:$ 1 $^{\circ} 19^{\prime} 22.4^{\prime \prime}$

The Boulder of St. Adalbert is an indicator erratic-Småland granite-that originated in southeastern Sweden (Figure 1). As much as 90\% of the boulder surface is colonised by lichens (Figure 9). The structure and texture of the granite is only visible just above ground level. This in situ boulder was dated with ${ }^{10}$ Be by Tylmann et al. (2019).

The ${ }^{10} \mathrm{Be}$ exposure age is $16.9+/-1.9 \mathrm{ka}$. This is an important scientific value of the object, which influences its geotouristic potential. It is the second largest erratic boulder in the Wielkopolska region, after the Boulder of St. Hedwig (see this article), and the oldest protected monument of inanimate nature in this part of Poland. In 1840, thanks to the local population, the boulder was entered in the land register as an object protected 'forever'. This regulation protected the boulder from destruction or use for construction purposes. Additionally, there is a legend connected with this boulder-St. Adalbert, speaking to the pagans, stood on its top, as if on a pulpit. When the saint drove away, two pits in the shape of human feet, were seen in the stone. There are also mysterious powers attributed to the boulder-in the distant past, a spring of miraculous water gushed out from under the boulder-who washed his eyes with it-he regained his sight.

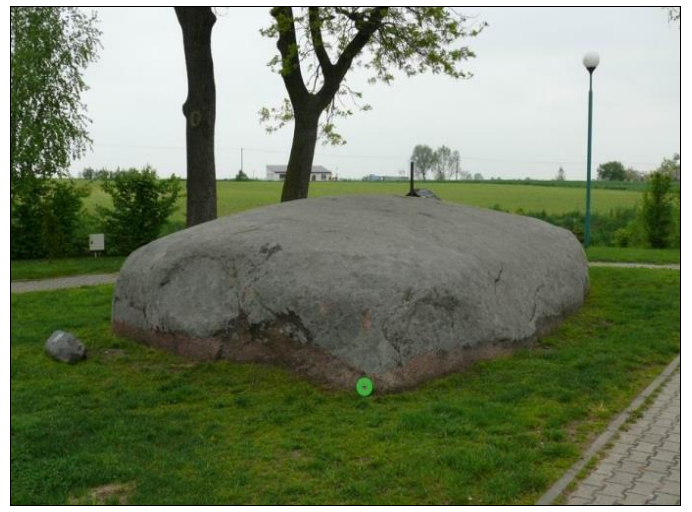

Figure 9. Boulder of St Adalbert, the oldest protected monument of inanimate nature in Wielkopolska

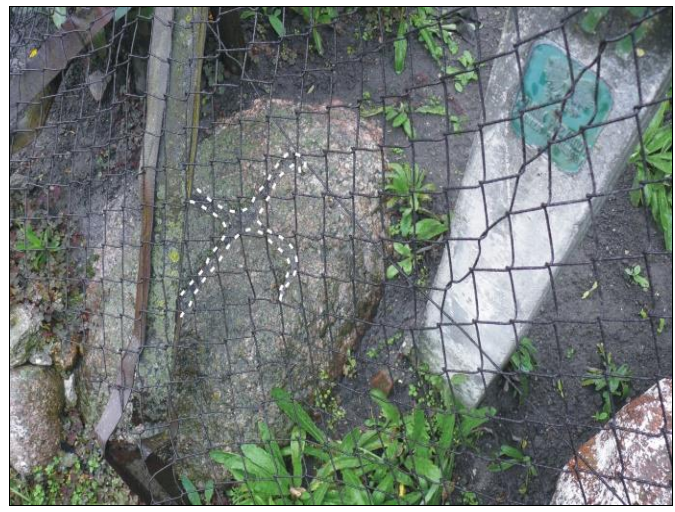

Figure 10. Boulder of Fire with a reversed swastika, an inanimate nature monument 
Today, the Boulder of St. Adalbert is an exceptional example of how such an object of inanimate nature heritage can be protected. The mayor of the nearby village of Budziejewko is also the custodian of the object and a local guide. Moreover, a geotourist can learn more on several information boards in Polish, English and German.

Piast (Eng. = name of the first historical Polish ruling dynasty, AD 9601370) by Lake Gopło (No. 6 in Figure 2); $\Phi: 5^{\circ} 3^{6}$ 11.1" $^{\prime \prime}:_{18}^{\circ} 23^{\prime} 37.5^{\prime \prime}$

The boulder occurs in situ among field thickets, on the east side of Lake Gopło, in the eastern part of the Wielkopolska region. It is only partially dug up, so its height is unknown. This in turn does not allow for calculating its volume and weight (Table 1).

The mineral composition and internal structure of the boulder indicate that it is an indicator erratic (Småland granite), which originated from the outcrops in southeastern Sweden (Figure 1). It is characterised by the occurrence of blue quartz crystals, which are typical of this indicator erratic (Bartholomäus \& Solcher, 2002). It is difficult to speak about the aesthetic values of the boulder-in terms of size it is one of the smaller stone blocks in the Wielkopolska region. A characteristic plate, rarely found in the Wielkopolska region, informs us that the boulder is an inanimate nature monument.

Gtaz Ognia (Eng. Boulder of Fire; No. 7 in Figure 2); $\Phi: 52^{\circ} 33^{\prime}$ 27.2" $\Delta$ : $18^{\circ} 22^{\prime} 24 \cdot 3^{\prime \prime} E$

The Boulder of Fire is equally small (Table 1) but much more interesting. It is pegmatitic granite, the Scandinavian origin of which, defined by geographical coordinates, is difficult to determine exactly. Therefore, it is not an indicator erratic. However, it is an inanimate nature monument as indicated by the appropriate plate (Figure 10). The Boulder of Fire is an object of cultural heritage due to the inverted swastika engraved on its upper surface. The right-facing form of a swastika, with the shape of the arms imitating the movement of the Sun (as seen from the northern hemisphere of the Earth) is often associated with solar cults, as the symbol of fire and the Sun (circle of rays). It was a lucky talisman and sometimes a symbol of goddesses and thus fertility. The symbol was already known to an ancient culture on the Indus River.

Due to the annexation of the swastika by the Third Reich this symbol is sometimes mistakenly regarded as a Germanic sign. However, the swastika has occurred all over the world (except Australia) from ancient times. One of the oldest cave paintings with the motif of a swastika dates from the Palaeolithic, about 10,000 years (Zasuń, 2011). Skoczylas and Zieliński (2006) wrote about other stonemason's marks, which might have specified to a stone workshop or times, when boulders underwent stone processing.

Unfortunately, access to the boulder is difficult because it is situated in a private garden, near the ferry harbour along the eastern branch of Lake Gopło. Due to this difficult access, it is only possible to estimate some dimensions of the boulder (Table 1).

The largest boulder in Poznań, Botanical Garden of Adam Mickiewicz University (No. 8 in Figure 2); $\Phi: 52^{\circ} 25^{\prime} 08.2^{\prime \prime} \Delta: 16^{\circ} 53^{\prime}$ O2..$^{\prime \prime}$

The largest erratic boulder in Poznan occurs ex situ. It was found in northwestern Poland, in the surface deposits left by the ice-sheet during the Pomeranian phase of the Vistulian glaciation $\left(15.2{ }^{14} \mathrm{C}\right.$ ka - Kozarski, 1986, 1988; Marks, 2002; 16.2 ka BP Kozarski, 1995; 14.8 $\pm 0.4{ }^{10} \mathrm{Be} \mathrm{ka}$ - Rinterknecht al., 2005, 2012; 16-17 ${ }^{10} \mathrm{Be} /{ }^{36} \mathrm{Cl} \mathrm{ka} \mathrm{BP}-$ Marks, 2012). It is not possible to precisely determine the source area of the boulder because it is not an indicator erratic. It represents metamorphic rocks (a gneiss) (Figure 11). The height of the boulder was greater when it was placed. It has sunk under its own weight to a depth of about $1 \mathrm{~m}$. The boulder is located in the Botanical Garden of Adam Mickiewicz University in Poznań. In addition to various plants that are protected and 
popularised in the Garden, as much as 3000 tons of rock materials of various fractions, including 10 large erratic boulders, have been collected (Górska-Zabielska, 2010, 2013, 2015b). Erratic boulders, exposed in the vicinity of animate nature, enrich the attractiveness of the Botanical Garden. Their scientific, educational and aesthetic value often influence Poznań inhabitants to visit the Garden.

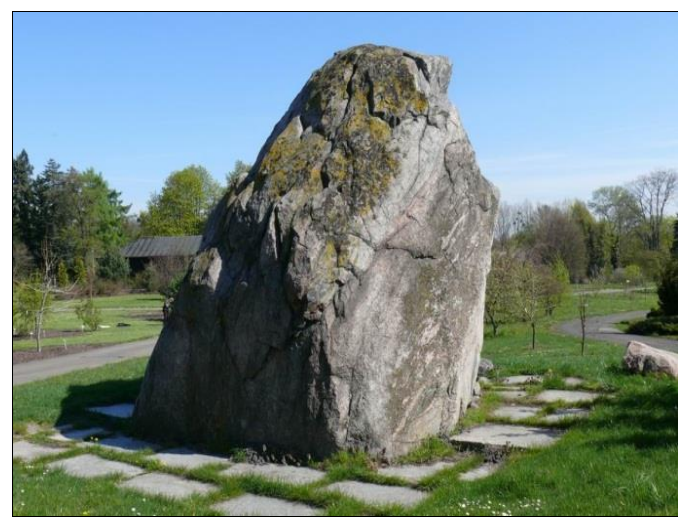

Figure 11. The largest boulder in Poznańgneiss-is located in the Botanical Garden of Adam Mickiewicz University in Poznań

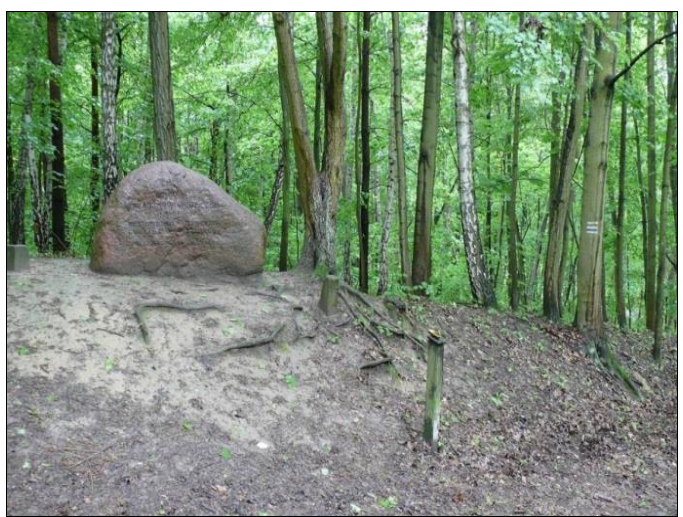

Figure 12. Boulder of Professor Adam Wodziczko-general view

\section{Boulder of Professor Adam Wodziczko, Wielkopolski National Park} (No. 9 in Figure 2); $\Phi: 52^{\circ} 14^{\prime} 59.0^{\prime \prime} \Delta: 16^{\circ} 48^{\prime} 58.1^{\prime \prime}$

The boulder of Professor Adam Wodziczko (Figure 12) is one of the five large erratic boulders that occur in the Wielkopolski National Park, which is located about $15 \mathrm{~km}$ to the south of Poznań, the main city in the Wielkopolska region. The highest scientific and educational values of the boulder result from the fact that it is an indicator erraticJäreda granite (Figure 13), the outcrop of which occurs in northern part of Småland source area (Figure 1). The boulder is named after the co-originator of the Wielkopolski National Park, professor of botany in Poznań, Adam Wodziczko. It occurs ex situ.

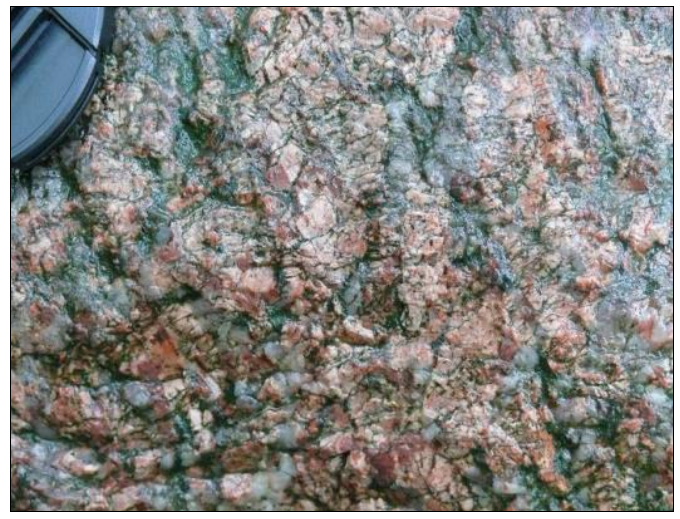

Figure 13. Details of the structure and texture of the Järeda granite

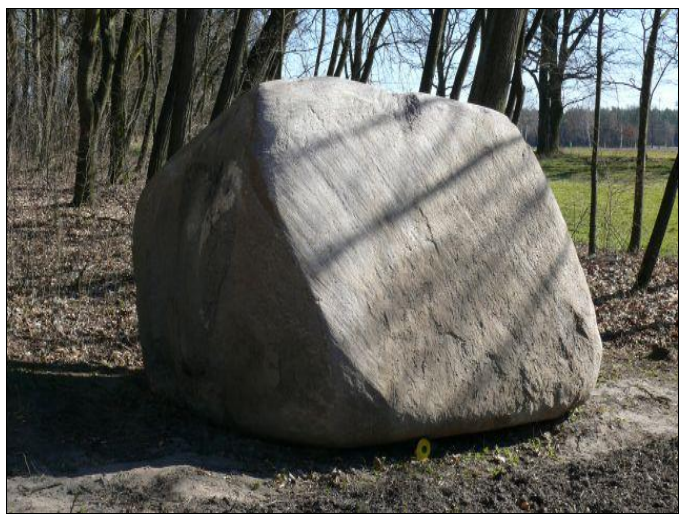

Figure 14. Boulder in Rogalin of Småland granite, general view from the side of the road No. 431; polished sides of the boulder with glacial striae are visible 
The described boulder is easily accessed at the intersection of forest roads and tourist trails, including the Trail of Professor A. Wodziczko. Not far from this boulder are other interesting geomorphological objects: Lake Kociołek (an evorsion pothole) and a fragment of the Buk-Mosina esker (called the 'Swedish Mountains'). Their cooccurrence indicates high geodiversity in this part of the Wielkopolska region.

It is also worth mentioning the Petrographic Garden, located near the headquarters of the Wielkopolski National Park in Jeziory, in which 20 Scandinavian indicator and auxiliary erratics have been placed for educational purposes. To preserve the geodiversity of the park and not change the position of the other four large erratic boulders, the boulders for the garden were brought from nearby gravel pits where there are deposits corresponding in terms of age to the surface deposits in the park. More information on the scientific, educational and geotourist values of the Petrographic Garden in Jeziory can be found in articles published by the author (Górska-Zabielska, 2008b, 2009).

Boulder in Rogalin (No. 10 in Figure 2); $\Phi: 5^{\circ} 14^{\prime} 15.6 " \Delta: 16^{\circ} 55^{\prime} 41.8^{\prime \prime}$

The boulder is an indicator erratic-Småland granite-with outcrops occurring in southeastern Sweden (Figure 1). Two polished perpendicular surfaces of the boulder, with visible glacial striae are noticeable (Figure 14). Moreover, closer observation of the boulder surface show the traces of exogenetic processes: the physical weathering of granite (exfoliation) and chemical weathering of feldspars (kaolinization).

The boulder was placed in the buffer zone of the Wielkopolski National Park quite recently, in 2015. It was found in the Kleczew open pit of the Brown Coal Mine in the eastern Wielkopolska region, at the Vistulian till layer at a depth of $20 \mathrm{~m}$ below ground level (108 $\mathrm{m}$ a.s.l.). The boulder in Rogalin is one of the few in the entire European region where Scandinavian material occurs which has been weighed (25.24 tons) (Table 1).

Boulder in the Dolskie Hills (No. 11 in Figure 2); $\Phi: 51^{\circ} 57^{\prime} 56.9 " \Delta: 17^{\circ}$ $09^{\prime} 05.8^{\prime \prime}$

The boulder is an indicator erratic-Jotnian sandstone. The outcrops of this rock occur in central Sweden (Dalarna) and at the Baltic Sea bottom (Figure 1). It has been a monument of inanimate nature since 1956; unfortunately, it is not accompanied by a plate informing visitors of its status. The boulder occurs in a small depression that is often filled with water, depending on the season. The total height of the boulder is unknown. It has been dug up as indicated by the earth embankment surrounding the boulder and its location in relation to the ground surface (Figure 15).

The boulder in the Dolskie Hills is particularly worthy of attention due to the preserved microforms of glacial erosion. They are well visible on the surface of the boulder as glacial striae and crescent chatter marks (grooves and scratches) (Figure 16). Both groups of forms can reveal the direction the ice-sheet was flowing only when they are observed on a bedrock in source areas. They were formed as a result of scouring against the crystalline bedrock when the boulder was transported in the bottom layer of an ice-sheet. The smoothness could also have resulted from the scratching of bedrock by a moving ice-sheet sole rich in incorporated pieces of rocks and sediments. This icesheet may have changed its direction of movement as indicated by various orientations of the microforms (Figure 16). Due to its scientific and educational values, the boulder is one of the most valuable objects of this type in the Wielkopolska region.

It significantly enhances the geodiversity of southern Wielkopolska, which is high even without it because the Dolskie Hills occur in the glacimarginal zone of the last glacial maximum (Vistulian glaciation). The boulder occurs in the for est, at the Dolskie Hills tourist trail about $4 \mathrm{~km}$ from the nearest asphalt road (No. 437). Due to this location it is difficult to reach the boulder quickly. The latest research (Tylmann et al. 
(2019) gives an example of another in situ boulder, from the neighborhood, which is far better exposed. It is a granite boulder located on a moraine hill close to Brześnica village. The ${ }^{10}$ Be exposure age of this boulder is $21.8+/-1.9 \mathrm{ka}$ (Tylmann et al., 2019), which is an excellent indicator of the ice sheet retreat after the Local Last Glacial Maximum. This important scientific value of the boulder rises its geoturistic attractiveness.

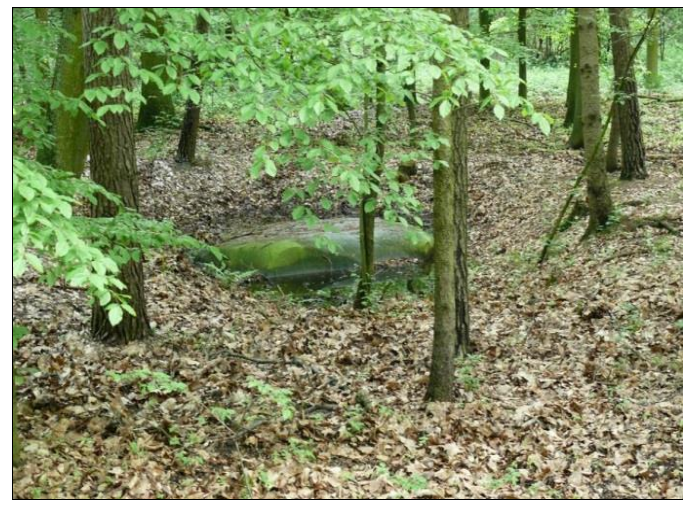

Figure 15. Monument of inanimate nature in the Dolskie Hills, general view

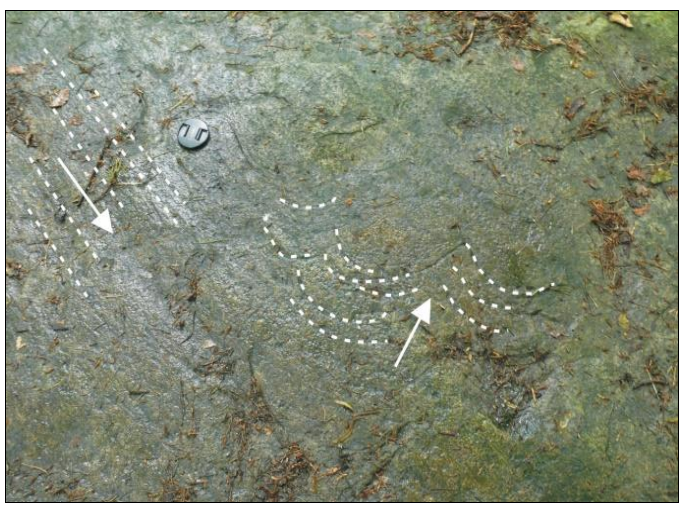

Figure 16. Variously directed glacial striae and crescent chatter marks on the Jotnian sandstone indicate the ice-sheet moved in two different directions. Arrows mark the direction of the ice-sheet movements

\section{Gtaz św. Jadwigi (Eng. Boulder of St. Hedwig) in southern} Wielkopolska (No. 12 in Figure 2); $\Phi: 51^{\circ} 49^{\prime} 58.5^{\prime \prime} \Delta: 17^{\circ} 56^{\prime} 50.0^{\prime \prime}$

The boulder of St. Hedwig is the largest erratic boulder in the Wielkopolska region (Figure 17) and the sixth largest in Poland. It is an indicator erratic-Småland granite (Figure 18) - that originated from outcrops in southeastern Sweden (Figure 1). It occurs in situ. The deposition of the Boulder of St. Hedwig to the south of the glacimarginal zone of the Vistulian glaciation in its maximum extent as well as its occurrence within the surface deposits indicate it was transported by the ice-sheet during the Wartanian (the late Saalian) glaciation (MIS 6, Marks et al., 2019).

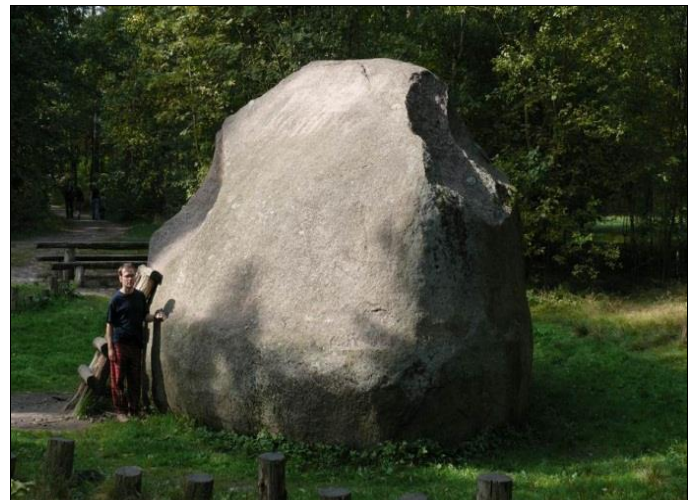

Figure 17. Boulder of St. Hedwig with visible damage to the object

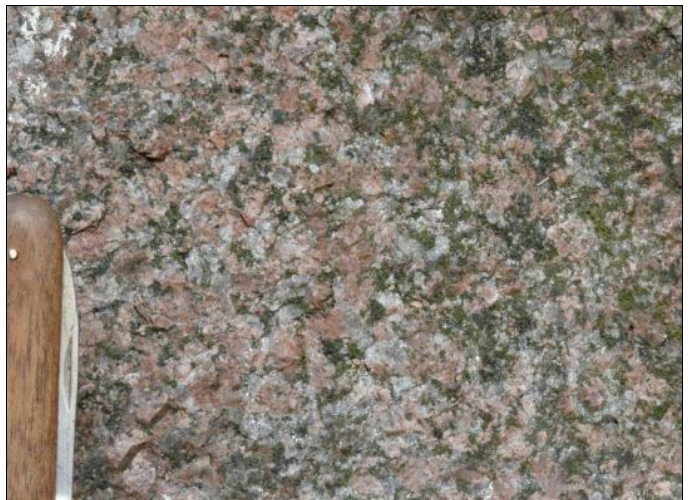

Figure 18. Details of the structure and texture of Småland granite 
The long distance from roads and forest location were factors that favoured attempts to split the boulder into smaller fragments. This is evidenced by traces of damage and cavities (Figure 17), which irretrievably lowered the scientific, educational and aesthetic values of the boulder with its polished surface and visible glacial striae. In the immediate vicinity of the boulder there is a convenient picnic spot. Unfortunately, there is no board with information about the boulder and its glacial transport from Scandinavia. This largest boulder in the Wielkopolska region was entered in the register of inanimate nature monuments on March 28, 1957.

\section{RESULTS OF EVALUATION ANALYSIS}

Twelve erratic boulders from the Wielkopolska region (Figure 2; Table 1) were evaluated for the first time (Table 3) to determine their potential to promote geotourism. The evaluation analysis was carried out using the categories and criteria presented in Table 2. In the scientific value category, the highest number of points (3 of 4 possible points) has been granted to three erratic boulders: the Enchanted Carriage (No. 3 in Table 3) in the Torun-Eberswalde Pradolina, the Boulder of St Adalbert (No. 5) and the boulder (No. 11) in the Dolskie Hills. They occur in situ and are indicator erratics. Two of them (No. 4 and 5) were dated with ${ }^{10} \mathrm{Be}$ in order to obtain an exposure age. They also co-create a very rich geodiversity in the vicinity of the geosites and therefore differ from the other evaluated erratic boulders. In the educational value category, the Boulder of St. Adalbert (No. 5) has the highest number of points (3 of 4 possible points), mainly due to the existing educational resources. A guided tour by the custodian of the monument of inanimate nature is available. Geotourists can use information boards written in Polish, English and German. The roofed picnic place, located near the Boulder of St Adalbert, can be used to conduct lessons in the field or for a short stop during a walking tour along the tourist trail. Unfortunately, none of the described boulders occur on a geotourist path. The erratic boulders are also not included in the widely available guide services.

In the economic value category only one erratic boulder received 2 points (of a possible 3). Access to the largest boulder in Poznan (No. 8, located within the Botanical Garden of Adam Mickiewicz University) is simple and there is some tourist infrastructure (picnic place, accommodation and provisioning) in the immediate vicinity (within $1 \mathrm{~km}$ ). Unfortunately, none of the local products (arts and crafts) are associated with the evaluated boulders nor represent them symbolically. In the conservation value category, three erratic boulders (Enchanted Inn, No. 4; Boulder of St. Adalbert, No. 5; and Boulder of Fire, No. 7) received the maximum number of points (4). The largest boulder in Poznan (No. 8), the Boulder of Prof. A. Wodziczko (No. 9) and the boulder in Rogalin (No. 10) are also highly rated because they are within a protected area (the Botanical Garden, Wielkopolski National Park and its immediate surroundings, respectively). The largest boulder in the Wielkopolska region, the Boulder of St. Hedwig (No. 12), has been irretrievably destroyed and therefore received a low rating. Nine of the described erratic boulders are legally protected as inanimate nature monuments. Only three (boulders Nos. 5, 6 and 7) are accompanied by characteristic plates, informing that they are protected legally.

Considering the additional value category, the only object that received the maximum number of points (3.5) is the Boulder of St. Adalbert (No. 5). It is strongly associated with cultural and historical values. It is named after the saint patron of Poland. There is also a legend connected with this boulder and mysterious powers have been attributed to it in the past. The object was the first protected erratic boulder in Poland. There is also notable ecological value-the Boulder of St. Adalbert is colonised by epilithic flora with little influence for their weathering. The aesthetic value associated with the size 
of the boulder, possibility of close observation and varied appearance have been observed in this outstanding object of abiotic nature. Fewer points in this category were allotted to the Enchanted Inn, which in contrast is not colonised by lichen flora.

Table 3. Evaluation analysis of the erratic boulders in the Wielkopolska region (western Poland)

\begin{tabular}{|c|c|c|c|c|c|c|c|c|c|c|c|c|c|c|c|c|c|c|c|c|c|c|c|c|}
\hline \multirow{2}{*}{ 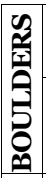 } & \multicolumn{5}{|c|}{$\begin{array}{l}\text { SCIENTIFIC } \\
\text { VALUE }\end{array}$} & \multicolumn{5}{|c|}{$\begin{array}{l}\text { EDUCATIONAL } \\
\text { VALUE } \\
\end{array}$} & \multicolumn{4}{|c|}{$\begin{array}{l}\text { ECONOMIC } \\
\text { VALUE }\end{array}$} & \multicolumn{5}{|c|}{$\begin{array}{c}\text { CONSERVATION } \\
\text { VALUE } \\
\end{array}$} & \multicolumn{4}{|c|}{$\begin{array}{l}\text { ADDITIONAL } \\
\text { VALUE }\end{array}$} & \multirow{2}{*}{ 是 } \\
\hline & $\mathrm{a}$ & $\mathrm{b}$ & $\mathrm{c}$ & $\mathrm{d}$ & 寻 & $\mathrm{a}$ & $\mathrm{b}$ & $\mathrm{c}$ & $d$ & $\underset{\Xi}{\Xi}$ & $\mathrm{a}$ & b & $\mathrm{c}$ & 灵 & $\mathrm{a}$ & b & $\mathrm{c}$ & $\mathrm{d}$ & $\underset{\varpi}{\Xi}$ & a & $\mathrm{b}$ & c & $\underset{\varpi}{\Xi}$ & \\
\hline 1. & $\mathrm{O}$ & 1 & O & 0.5 & 1.5 & 1 & 1 & O & O & 2 & 0.5 & 0.5 & 0 & 1 & 0.5 & 0.5 & O & 1 & 2 & 0.5 & 0.5 & 1.5 & 2.5 & 9 \\
\hline 2. & 1 & 1 & $\mathrm{O}$ & 0.5 & 2.5 & 1 & 1 & O & O & 2 & 0.5 & 0.5 & 0 & 1 & 0 & $\mathrm{O}$ & 1 & 1 & 2 & $\mathrm{O}$ & 0 & 1.5 & 1.5 & 9 \\
\hline 3. & 1 & 1 & 0.5 & 0.5 & 3 & 1 & 1 & O & $\mathrm{O}$ & 2 & 0.5 & 1 & 0 & 1.5 & 0.5 & 0.5 & 0.5 & 1 & 2.5 & 1 & O & 1.75 & 2.75 & 11.75 \\
\hline 4. & 1 & o & 0 & 1 & 2 & 1 & 1 & 0 & 0 & 2 & o & 0 & 0 & 0 & 1 & 1 & 1 & 1 & 4 & 1 & 0.5 & 1.5 & 3 & 11 \\
\hline 5. & 1 & 1 & 0 & 1 & 3 & 0.5 & 1 & 0.5 & 1 & 3 & 0.5 & 1 & 0 & 1.5 & 1 & 1 & 1 & 1 & 4 & 1 & 1 & 1.5 & 3.5 & 15 \\
\hline 6. & 1 & 1 & $\mathrm{O}$ & 0.5 & 2.5 & 0.5 & 0.5 & 0 & $\mathrm{O}$ & 1 & 0.5 & $\mathrm{O}$ & 0 & 0.5 & $\mathrm{O}$ & $\mathrm{O}$ & 1 & 1 & 2 & $\mathrm{O}$ & $\mathrm{O}$ & 0.5 & 0.5 & 6,5 \\
\hline 7. & 1 & 1 & 0 & 0.5 & 2.5 & 0.5 & 0.5 & 0 & 0 & 1 & 0 & 0 & 0 & 0 & 1 & 1 & 1 & 1 & 4 & 1 & 0 & 0.5 & 1.5 & 9 \\
\hline 8. & o & 0 & o & 0.5 & 0.5 & 0.5 & 0.5 & O & 1 & 2 & 1 & 1 & 0 & 2 & 1 & 1 & 1 & 0.5 & 3.5 & O & 0.5 & 1.75 & 2.25 & 10.25 \\
\hline 9. & 0 & 1 & 0.5 & 0.5 & 2 & 0.5 & 0.5 & 0 & 0.5 & 1.5 & 0.5 & O & 0 & 0.5 & 1 & 1 & 1 & 0.5 & 3.5 & 1 & 0 & 1.25 & 2.25 & 9,75 \\
\hline 10. & 0 & 1 & $\mathrm{O}$ & 0.5 & 1.5 & 0.5 & 0.5 & 0.5 & 0 & 1.5 & 0.5 & 0.5 & 0 & 1 & 1 & 1 & 1 & 0.5 & 3.5 & 0 & 0 & 1.5 & 1.5 & 9 \\
\hline 11. & 1 & 1 & 0.5 & 0.5 & 3 & 0.5 & 0.5 & 0.5 & 0 & 1.5 & 0.5 & $\mathrm{O}$ & 0 & 0.5 & 0 & O & 1 & 1 & 2 & O & 0.5 & 0.75 & 1.25 & 8.25 \\
\hline 12. & 1 & 1 & 0 & 0.5 & 2.5 & 1 & 0.5 & 0.5 & 0.5 & 2.5 & 0.5 & 0.5 & 0 & 1 & 0.5 & 0.5 & 0 & 1 & 2 & 1 & $\mathrm{O}$ & 1.5 & 2.5 & 10.5 \\
\hline
\end{tabular}

Legend: Numbers stay for boulders: 1. Johnny, 2. Lutom,3. Enchanted carriage, 4. Enchanted Inn, 5. Boulder of St Adalbert, 6. Piast, 7. Boulder of Fire, 8. The largest boulder in Poznań, 9. Boulder of

Prof. A. Wodziczko, 10. Boulder in Rogalin, 11. Boulder in the Dolskie Hills, 12. Boulder of St Hedwig

SCIENTIFIC VALUE: $\mathrm{a}$ - location after ice thawing; $\mathrm{b}$ - type of erratic; $\mathrm{c}$ - number of different features visible in geosite; and $d$ - scientific knowledge.

EDUCATIONAL VALUE: $a$ - representativeness and visibility/clarity of features; $b$ - quality of educational example and educational usefulness; c - existing educational products; and d - existing forms of use for educational purposes (e.g. specialist tour, guided tour).

ECONOMIC VALUE: a - accessibility; $\mathrm{b}$ - presence of tourist infrastructure; and $\mathrm{c}$ - local products.

CONSERVATION VALUE: $\mathrm{a}$ - existing threats and the risk of damage; $\mathrm{b}$ - potential threats and the risk of damage; $\mathrm{c}$ - current state; and $\mathrm{d}$ - legal protection status.

ADDITIONAL VALUE: a - cultural values (historical, archaeological, religious) connected with the abiotic site; $b$ - ecological value; and $c$ - aesthetic value (number of colours, structure types, viewpoints, exposed position and volume).

Table 4. Evaluation of the potential of erratic boulders in the Wielkopolska region to promote geotourism

\begin{tabular}{|c|c|c|c|}
\hline Score & & Potential for geotourism & Numbers of erratic boulders \\
\hline $0-7$ & & low & 6 \\
\hline $7.25-11$ & & medium & $1,2,4,7-12$ \\
\hline $11.25-13.25$ & & high & 3 \\
\hline $13 \cdot 5-15$ & very high & 5 \\
\hline
\end{tabular}

In summary, the Boulder of St. Adalbert (No. 5) has the highest (among the analysed objects) potential to promote geotourism in the Wielkopolska region (Table 4). The Enchanted Carriage (No. 3) may promote geotourism to a slightly lesser degree. Eight erratic boulders have a medium potential to promote this part of geoheritage through tourism. The only object which has very low potential for geotourism promotion is the Boulder of Fire 
The Most Valuable Erratic Boulders in the Wielkopolska Region

of Western Poland and their Potential to Promote Geotourism

(No. 6). With limited access, poor exposure and a longer distance from any tourist infrastructure, it has the smallest chance of promoting the beauty of inanimate nature.

\section{CONCLUSIONS}

The erratic boulders described in this study are lithosphere resources and constitute the geological heritage of the Wielkopolska region. They represent different petrographic types, and thus originate from different source areas in Scandinavia. Their state of preservation is also varied. Their morphological features are evidence of the processes of glacial erosion, which affected them during transport from source areas to the places of deposition, as well as the periglacial processes occurring on the foreland of the retreating ice-sheet. All these values indicate the erratic boulders are undoubtedly elements of the geodiversity of the region. Eight of the twelve erratic boulders occur in situ and ten are indicator erratics. These significant scientific values do not always determine the final result of the evaluation analysis. The Enchanted Carriage and the boulder in the Dolskie Hills, both with high scientific value, do not have the greatest potential to promote geotourism. The erratic boulders in the Wielkopolska region (except the boulder in Rogalin) are geosites (Reynard, 2004; Migon, 2012) and are entered in the Central Register of Polish Geosites (http://geoportal.pgi.gov.pl/ portal/page/portal/geostanowiska). All the studied erratic boulders are protected as inanimate natural monument (10 objects) or occur in legal protected areas (2 objects).

Several of the described boulders represent cultural heritage. They appear in folk legends and tales, they were the objects of religious cults, or they are named after prominent religious figures and those associated with the region. Sometimes they have a fanciful shape, which undoubtedly contributes to their aesthetic value, together with their dimensions. The results of the evaluation analysis indicate that the cultural and aesthetic value of the erratic boulders in the Wielkopolska region can play a significant role in the promotion of inanimate nature. Other than examples of vandalism, boulders in the Wielkopolska landscape trigger positive reactions and are major tourist attractions in the region. Boulders have always been a favourite destination for tourist trips and play an educational role on nature paths. The boulders may be better known if access to them was facilitated by marking geotourist trails with signposts.

In light of the evaluation analysis, such erratic boulders have great potential to promote geotourism. This would be more effective if the boulders were accompanied by information boards presenting material in an accessible way about source areas and processes over time that have affected the boulders. Per the evaluation analysis, the Boulder of St. Adalbert may be the most useful in terms of providing information and promoting the protection of the remains of the glacial period. Above all, it is a model object to be used in education. The scientific values of the boulder could be higher but its surface is colonised by lichens and the surrounding area has low geodiversity.

Easy access to the boulder and the existing tourist infrastructure may encourage geotourism. The boulder has been well rated because it is protected by law and its historical and cultural value is high. Moreover, it has the highest additional value (important for tourists) of all the analysed boulders. The evaluation analysis demonstrates that the additional value of inanimate natural objects may have a strong influence on the effective promotion of geotourism in the Wielkopolska region.

\section{Acknowledgements}

The author would like to acknowledge Małgorzata Gościńska-Kolanko, who sketched two drawings (Nos. 1 and 2). SCRIBENDI prepared the final version of English translation of the text. 


\section{Funding information}

The research was funded by Adam Mickiewicz University and the Polish Geological Institute - National Research Institute.

\section{REFERENCES}

Atkinson, N. (2007). A statistial technique for determining the source of glacially transported granite erratics in the Queen Elizabeth Islands, Nunavut. Canadian Journal of Earth Science, 44(1), p. 43-59.

Bartholomäus, W.A. \& Solcher, J. (2002). The less known properties of blue quartz. Geschiebekunde Aktuell, 18(3), p. 99-106.

Böse, M. \& Górska, M. (1995). Lithostratigraphical studies in the outcrop at Ujście, Toruń-Eberswalde Pradolina, western Poland. Eiszeitalter und Gegenwart, 45, p. 1-14.

Bouchard, M.A. \& Salonen, V.P. (1989). Glacial dispersal of boulders in the James Bay Lowlands of Quebec, Canada. Boreas, 18, p. 189-199.

Bouchard, M.A. \& Salonen, V.P. (1990). Boulder transport in shield areas. In R. Kujansuu and M. Saarnisto (ed.), Glacial indicator tracing. Balkema, Rotterdam, p. 87-107.

Boulton, G.S. \& Hagdorn, M. (2006). Glaciology of the British Isles Ice Sheet during the last glacial cycle: form, flow, streams and lobes. Quaternary Science Reviews, 25, p. 3359-3390.

Brilha, J. (2016). Inventory and Quantitative Assessment of Geosites and Geodiversity Sites: a Review. Geoheritage, 8(2), p. 119-134.

Bruschi, V.M. \& Cendrero, A. (2005). Geosite Evaluation. Can we measure intangible values? Il Quaternario, 18(1), p. 293-306.

Bruschi, V.M. \& Cendrero, A. (2009). Direct and parametric methods for the assessment of geosites and geomorphosites. In E. Reynard, P. Coratza \& G. Regolini-Bissig (eds), Geomorphosites. Verlag Dr. Friedrich Pfeil, München. Section II, p. 73-88.

Chrząszczewski, W. (2009). Stoneman spod Konina [Stoneman from Konin]. Nowy kamieniarz, 43(7), p. 40-44

Chylińska, D. \& Kołodziejczyk, K. (2018). Geotourism in an urban space? Open Geoscience, 10, p. $297-310$.

Czernicka-Chodkowska, D. (1983). Zabytkowe głazy narzutowe na obszarze Polski [Historic erratic boulders in Poland]. Katalog Muzeum Ziemi PAN. Wydawnictwo Geologiczne, Warszawa.

Czubla, P. \& Sokołowski, R. (2019). Did the Baltic Ice Stream exist during the Late Saalian? New data from the northern Wielkopolska and Eastern Pomerania regions, Poland. In A. Börner, H. Hüneke, S. Lorenz (eds.), Field Symposium of the INQUA PeriBaltic Working Group "From Weichselian Ice-Sheet Dynamics to Holocene Land Use Development in Western Pomerania and Mecklenburg". Abstract Volume. Scientific Technical Report STR 19/01, Potsdam: GFZ German Research Centre for Geosciences, p. 21-22, DOI: https://doi.org/10.2312/GFZ.b103-19012.

Czubla, P. (2015). Eratyki fennoskandzkie w osadach glacjalnych Polski i ich znaczenie badawcze [Fennoscandian erratics in glacial sediments of Poland and their research significance]. Wydawnictwo Uniwersytetu Łódzkiego, Łódź, pp. 335.

Dilabio, R.N.W. (1990). Glacial dispersal trains. In R. Kujansuu \& M. Saarnisto (ed), Glacial indicator tracing. Balkema, Rotterdam, p. 109-122.

Duraj, M., Niemiec, D., Cheng, X. \& Koleňák P. (2017). Vestiges of glacial action in Ostrava: their significance for an application in geotourism. World Multidisciplinary Earth Sciences Symposium (WMESS), IOP Conf. Series: Earth and Environmental Science, p. 95, DOI: 10.1088/1755-1315/95/5/052014.

Dyke, A.S. \& Morris, T.F. (1988). Drumlin fields, dispersal trains and ice streams in Arctic Canada. Can. Geographer, 32, p. 86-90.

Dzierżek, J. \& Zreda, M. (2007). Timing and style of deglaciation of north eastern Poland from cosmogenic ${ }^{36} \mathrm{Cl}$ dating of glacial and glaciofluvial deposits. Geological Quarterly, 51(2), p. 203-216.

Gałązka, D. (2004). Zastosowanie metody makroskopowego oznaczania eratyków przewodnich do lokalizacji obszarów źródłowych wybranych kier jurajskich [Application of macroscopic identification methods for index erratics to locate source areas of selected Jurassic glacial rafts]. Przegląd Geologiczny, 52(4), p. 349-350.

Głowińska, A. (1932). Materjały do inwentarza zabytkowych głazów narzutowych w Polsce [Materials for inventory of historic erratic boulders in Poland]. Ochrona Przyrody. Organ Państwowej Rady Ochrony Przyrody, Warszawa, 12, p. 81-88.

Górska, M. (2006). Fennoscandian erratics in glacial deposits of the Polish Lowland - methodical aspects. Studia Quaternaria, 23, p. 11-15.

Górska-Zabielska, M., (2008a), Fennoskandzkie obszary alimentacyjne osadów akumulacji glacjalnej i glacjofluwialnej lobu Odry [Fennoscandian mother regions of glacial and fluvioglacial deposits of the Odra lobe north-western Poland and north-eastern Germany]. Wydawnictwo Naukowe Uniwersytetu im. Adama Mickiewicza w Poznaniu, 78.

Górska-Zabielska, M. (2008b). Ogródek petrograficzny Wielkopolskiego Parku Narodowego w Jeziorach [Petrographic garden in the Wielkopolski National Park in Jeziory]. Bogucki Wydawnictwo Naukowe, Poznań, pp. 24. 
The Most Valuable Erratic Boulders in the Wielkopolska Region of Western Poland and their Potential to Promote Geotourism

Górska-Zabielska, M. (2009). Ogródek petrograficzny Wielkopolskiego Parku Narodowego [Petrographic garden of the Wielkopolski National Park]. In B. Walna, L. Kaczmarek, M. Lorenc \& R. Dondajewska (eds). Wielkopolski Park Narodowy w badaniach przyrodniczych, Poznań-Jeziory, p. 225-235.

Górska-Zabielska, M. (2010). Głazy narzutowe w Wielkopolsce [Glacial erratic boulders in Wielkopolska]. Prace i Studia z Geografii i Geologii, 18. Bogucki Wydawnictwo Naukowe.

Górska-Zabielska, M. (2013). Geowalory Ogrodu Botanicznego UAM w Poznaniu [Geovalues of the Botanic Garden of A. Mickiewicz University in Poznań]. Badania Fizjograficzne, Seria A - Geografia Fizyczna, R. IV (A63), p. 51-66.

Górska-Zabielska, M. (2015). Najcenniejsze głazy narzutowe w Wielkopolsce i ich potencjal geoturystyczny [The most precious erratic boulders in Wielkopolska (Greater Poland) and their geotouristic potential]. Przeglad Geologiczny, 63(8), p. 455-463.

Górska-Zabielska, M. (2016). Erratic disappearances. Academia 1 (49) http://scienceonline.pan.pl/index.php/nasze-teksty/nauki-o-ziemi/item/522-erratic-disappearances

Górska-Zabielska, M. (2020). New geotouristic objects in southern Podlasie. Przeglad Geologiczny, 68(2):91-99.

Górska-Zabielska, M. \& Dobracki, R. (2015). Petrographic Garden in Moryń - a new geotouristic attraction in western Poland. Landform Analysis, 29, p. 73-80.

Górska-Zabielska, M. \& Kamieńska, K. (2017). Geotourism potential of the "Połczyn Switzerland" area as a support for the planned geopark named "Postglacial land of the Drawa and Dębnica rivers". Quaestiones Geographicae, 36(1), p. 15-31.

Górska-Zabielska, M., Kusztal, P. \& Witkowska, K. (2019a). Selected erratic boulders of the north-western edge of the Holy Cross Mountains - contemporary significance and geotouristic potential [in Polish]. Przeglad Geologiczny, 67(9), p. 767-774; doi: http://dx.doi.org/10.7306/2019.45

Górska-Zabielska, M. \& Wachecka-Kotkowska, L. (2015). Petrografia żwirów i eratyki przewodnie w osadach wodnolodowcowych jako przesłanki wnioskowania na temat źródeł i kierunków transportu materiału w obszarze między Piotrkowem Trybunalskim, Radomskiem a Przedborzem (środkowa Polska) [The petrography of gravels and indicator erathics in the glacial sediments as premises for inference about the sources and directions of glacial transport in the area between Piotrków Trybunalski, Radom and Przedbórz (central Poland)]. Acta Geographica Lodziensis, 103, p. 57-77.

Górska-Zabielska, M., Witkowska, K., Pisarska, M., Jońca, B. \& Musiał, R. (2019b, in prep.). Inanimate nature objects in the opinion of the Kielce region's local community.

Górska-Zabielska, M., Witkowska, K., Pisarska, M., Musiał, R. \& Jońca, B. (2019c). The selected erratic boulders in the Świętokrzyskie Province (Central Poland) and their potential to promote geotourism. Geoheritage 12, 30; https://doi.org/10.1007/s12371-020-00453-8

Górska-Zabielska, M. \& Zabielski, R. (2018). Geotourism Development in an Urban Area based on the Local Geological Heritage (Pruszków, Central Mazovia, Poland). In M.J. Thornbush \& C.D. Allen (eds.), Urban Geomorphology. Landforms and Processes in Cities, p. 37-54.

Gray, M. (2013). Geodiversity: valuing and conserving abiotic nature. Wiley Blackwell, Chichester.

Gray, M. (2018). Geodiversity: the backbone of geoheritage and geoconservation. In E. Reynard \& J. Brilha (eds.), Geoheritage: assessment, protection, and management. Elsevier, Amsterdam, p. 13-25.

Grimmberger, G. (2017). Der Davids-Stein bei Utzedel - ein „neues altes“ Geotop. Geschiebekunde Aktuell, 33(3), p. 101-103 http://geoportal.pgi.gov.pl/portal/page/portal/geostanowiska access 20.02.2019

Ivy-Ochs, S. \& Kober, F. (2008). Surface exposure dating with cosmogenic nuclides. Eiszeitalter und Gegenwart. Quaternary Science Journal, 57, p. 179-209.

Kozarski, S. (1986). Timescales and the rhythm of Vistulian geomorphic events in the Polish Lowland. Czasopismo Geograficzne, 57, p. 247-270 (in Polish with English summary) .

Kozarski, S. (1988). Time and dynamics of the Last Scandinavian Ice-Sheet retreat from north western Poland. Geographia Polonica, 55, p. 91-101.

Kozarski, S. (1995). Deglaciation of north western Poland: environmental conditions and geosystem transformation $\sim 20$ ka - 10ka BP. Dokumentacja Geograficzna, 1, pp. 82 (in Polish with English summary).

Krawiec, F. (1933). Ochrona głazów narzutowych w Wielkopolsce [Protection of glacial erratic boulders in Wielkopolska]. Wydawnictwo Okręgowego Komitetu Ochrony Przyrody na Wielkopolskę i Pomorze. Państwowa Rada Ochrony Przyrody, Poznań, 4, p. 24-32.

Kubalíková, L. (2013). Geomorphosite assessment for geotourism purposes. Czech Journal of Tourism, 2(2), p. 80-104.

Liedtke, H. (1981). Die nordischen Vereisungen in Mitteleuropa. Forschungen zur deutschen Landeskunde. Band 204, Trier, pp. 308.

Lüttig, G. (2005). Geschiebezählungen im westlichen Mecklenburg. Archiv für Geschiebekunde, 4(9), p. 569-608.

Marks, L. (2002). Last Glacial Maximum in Poland. Quaternary Science Reviews, 21, p. 103-110.

Marks, L. (2012). Timing of the Late Vistulian (Weichselian) glacial phases in Poland. Quaternary Science Reviews 44:81-88 https://doi.org/10.1016/j.quascirev.2010.08.008

Marks, L., Bińka, K., Woronko, B., Majecka, A. \& Teodorski, A. (2019). Revision of the late Middle Pleistocene stratigraphy and palaeoclimate in Poland. Quaternary International, https://doi: 10.1016/j.quaint.2019.02.023 
Meyer, K.D. \& Lüttig, G. (2007). Was verstehen wir unter einem “Leitgeschiebe”? Geschiebeaktuell, 23(4), p. 106-121.

Meyer, K.D. (2004). Großgeschiebe auf Rügen. Schriftenreihe der Deutschen Geologischen Gesellschaft, 36, p. $103-109$. Migoń, P. (2012). Geoturystyka [Geotourism]. Wydawnictwo Naukowe PWN, Warszawa.

Motta, L. \& Motta, M., (2007), Erratic blocks: from protector beings to geosites to be protected. Geological Society, London, Special Publications, 273, p. 315-327, https://doi.org/10.1144/GSL.SP.2007.273.01.24.

Najwer, A. \& Zwoliński, Z. (2014). Semantics and geodiversity assessment methods - review and research proposal. Landform Analysis, 26, p. 115-127 [in Polish with English abstract].

Obst, K. (2005). Der "Buskam” von Göhren/Rügen - ein Riesenfindling aus Hammer-Granit. Geschiebekunde Aktuell, 21(2), p. 34-44.

Pereira, P., Pereira, D. \& Caetano Alves, M.I. (2007). Geomorphosite assessment in Montesinho Natural Park (Portugal). Geographica Helvetica, 62(3), p. 159-168.

Piotrowski, K. (2008). Good idea for business. Masonry of boulders. Nowy Kamieniarz, 34(5), p. 58-62 [in Polish].

Reynard, E. \& Brilha, J. (2018). Geoheritage: a multidisciplinary and applied research topic. In E. Reynard, J. Brilha (eds.), Geoheritage: assessment, protection, and management. Elsevier, Amsterdam, p. 433-438.

Reynard, E. (2004). Protecting Stones: conservation of erratic blocks in Switzerland. In R. Prikryl (ed.), Dimension Stone. New perspectives for a traditional building material, Leiden, Balkema, p. 3-7.

Reynard, E. (2005). Geomorphological sites, public policies and property rights. Conceptualization and examples from Switzerland. Il Quaternario, 18(1), p. 323-332.

Reynard, E., (2008), Scientific research and tourist promotion of geomorphological heritage. Geografia Fisica e Dinamica Quaternaria, 31, p. 225-230.

Reynard, E. (2012). Geoheritage protection and promotion in Switzerland. European Geologist, 34, p. 44-47.

Reynard, E. (2015). Erratic boulders in Switzerland, a geological and cultural heritage. Geophysical Research Abstracts, 17, p. 4415. https://meetingorganizer.copernicus.org/EGU2015/EGU2015-4415.pdf

Reynard, E., Regolini-Bissig, G., Kozlik, L. \& Benedatti, S. (2009). Assessment and promotion of cultural geomorphosites in the Trient Valley (Switzerland). Memorie descrittive della Carta Geologica d'Italia, 87, p. 181-189.

Rinterknecht, V., Braucher, R., Böse, M., Bourlès, D. \& Mercier, J.L. (2012). Late Quaternary ice sheet extents in northeastern Germany inferred from surface exposure dating. Quaternary Science Reviews, 44, p. 89-95.

Rinterknecht, V., Marks, L., Piotrowski, J.A., Raisbeck, G.M., Yiou, F., Brook, E.J. \& Clark, P.U. (2005). Cosmogenic ${ }^{10}$ Be ages on the Pomeranian Moraine, Poland. Boreas, 34(2), p. 186-191.

Schulz, W. (1964). Die Findlinge Mecklenburgs als Naturdenkmäler. Archiv für Naturschutz, 4(3), p. 99-126.

Schulz, W. (1996). Zur Bedeutung der Korngröße bei Geschiebezählungen. Der Geschiebesammler, 29(3), p. 91-102.

Skoczylas, J., Zieliński, P. (2006). Znaki kamieniarskie a początki średniowiecznego kamieniarstwa [Stone signs and the beginnings of medieval masonry]. Świat kamienia, 6, p. 138-141.

Speetzen, E. (1998). Findlinge in Nordrhein-Westfalen und angrenzenden Gebieten. Krefeld (GLA).

Stokes, C.R. \& Clark, C.D. (1999). Geomorphological criteria for identifying Pleistocene ice streams. Annals of Glaciology, 28, p. 67-75.

Svenson, Ch. (2005). Geschützte Findlinge der Insel Rügen. Landesamt für Umwelt, Naturschutz und Geologie Mecklenburg-Vorpommern, Güstrow.

Szulczewski, J.W. (1924). W sprawie ochrony głazów narzutowych Wielkopolski [On the protection of Wielkopolska's glacial erratic boulders]. Ochrona Przyrody. Organ Państwowej Rady Ochrony Przyrody, Warszawa, 4, p. 35-40.

Treichel, F. (1959). Ein riesiger Findling in Norddeutschland. Der Aufschluss, 10(12), p. 326-328.

Tylmann, K., Rinterknecht, V.R., Woźniak, P.P., Bourles, D., Schimmelpfennig, I., Guilou, V. \& Aster Team. (2019). The Local Last Glacial Maximum of the southern Scandinavian Ice Sheet front: cosmogenic nuclide dating of erratics in northern Poland. Quaternary Science Reviews, 219, p. 36-46.

Tylmann, K., Woźniak, P.P. \& Rinterknecht, V.R. (2018). Erratics selection for cosmogenic nuclide exposure dating - an optimization approach. Baltica, 31(2), p. 100-114.

Woźniak, P.P., Tylmann, K., Kobiela, A. (2015). Erratic boulders of the Trójmiejski Landscape Park - potential for research and geotourism. Przegląd Geologiczny, 63(4), p. 256-262 [in Polish].

Wright, J.D. (2000). Global Climate Change in Marine Stable Isotope Records. In J.S. Noller, J.M. Sowers, W.R. Lettis (eds), Quaternary geochronology: methods and applications. American Geophysical Union

Zasun, A. (2011). Swastika -a few reflections on the symbol. Prace Naukowe Akademii im. Jana Dtugosza w Częstochowie, Seria: Res Politicae, part IV, p. 235-252 [in Polish].

Zecha, S. \& Schiller, T. (2015). Nature as a treasure map! Teaching geoscience with the help of earthcaches?! Geophysical Research Abstracts, 17 https://meetingorganizer.copernicus.org/EGU2015/EGU2015-3968-1.pdf

Submitted:

16.12.2020
Revised:

29.04.2020
Accepted and published online

08.05.2020 